\title{
Who benefits from the leverage in LBOs?
}

\author{
Tim Jenkinson \\ Saïd Business School, Oxford University and CEPR \\ Rüdiger Stucke \\ Saïd Business School and Oxford-Man Institute, Oxford University
}

\begin{abstract}
Tax savings associated with increased levels of debt are often thought to be an important source of returns for private equity funds conducting leveraged buyouts (LBOs). However, as leverage is available to all bidders, the vendors may appropriate any benefits in the form of the takeover premium. For the 100 largest U.S. public-to-private LBOs since 2003, we estimate the size of the additional tax benefits available to private equity purchasers. We find a strong cross-sectional relationship between tax savings and the size of takeover premia; and on average the latter are around twice the size of the former. Consequently, the tax savings from increasing financial leverage essentially accrue to the previous shareholders rather than the private equity fund that conducts the LBO. It is, therefore, unlikely that (ex ante predictable) tax savings are an important source of returns for private equity funds. Furthermore, policy proposals that aim to restrict leverage or the taxdeductibility of debt are likely to have their impact mainly on existing owners of companies.
\end{abstract}

JEL classification: G34, H2

Keywords: Leveraged buyouts, taxes, private equity, takeover premium

Draft: 28 February 2011

The authors would like to thank Michael Devereux, Merle Erickson, Clemens Fuest, Doug Shackelford, Tracy Yue Wang, as well as participants at the CFEA 2010 conference at University of Maryland, the University of North Carolina Tax Symposium 2010, the University of Oxford Tax Symposium 2009, and seminar participants at Zurich, HEC Paris and Oxford for valuable comments. 


\section{Introduction}

Recent years have witnessed a rapid growth in investors' allocations to Private Equity (PE), and in particular to funds focused on Leveraged Buyouts (LBOs). The size of individual funds has grown significantly - with some funds reaching \$20 billion - and, accordingly, larger and larger companies have become potential LBO targets. Indeed, one of the main reasons that private equity has attracted so much attention recently is that public companies have increasingly been taken private via an LBO. This has raised questions as to the rationale for LBOs. Clearly, PE funds conduct LBOs only if they believe they can create attractive returns for their investors. These returns could derive from various sources: an increase in growth and efficiency as part of a different governance model that strongly aligns and sharpens management incentives in a highly leveraged environment (see Jensen (1986, 1989)); taking advantage of general movements in market prices, i.e. timing the exit until favorable market conditions; or from financial engineering, i.e. reducing the post-tax cost of capital by employing a much higher proportion of debt in the capital structure. In this paper we focus on this latter source of potential returns.

Not surprisingly, politicians and the media have been quick to notice the potential impact of LBOs of national tax revenues. Tax savings associated with debt interest payments can quickly transform a large net contributor into a non-tax payer. However, the size of potential tax shields is not straightforward to estimate, since these depend on numerous factors, such as the dynamics of the capital structure, the type of debt, the projections of future earnings, as well as carried forward tax positions. The first contribution of this paper is to quantify the size of the expected corporate tax savings associated with high levels of debt in LBOs (see Graham (1996a, 2000, 2001) for a discussion of the general issues regarding the value of debt tax shields). Whilst absolute $\$$ amounts of taxes may hit the headlines, it is really the size of the tax savings relative to the value of the acquired firm that is of most interest. However, systematic evidence on enterprise values is only available for the subset of LBO transactions associated with the acquisition of public companies, since market values do not exist for private companies and 
transaction values are often not disclosed. Consequently, in this paper we focus on these public-to-private LBOs.

The growth of public-to-private LBOs has been most marked in the U.S. Between 2003-08 there were 259 LBOs of companies that were listed on a U.S. stock exchange, which had a combined transaction value of $\$ 635$ billion. In this paper we focus on the largest 100 companies within this group (which comprised $80 \%$ of the total value). In each case we produce various scenarios for the net present value (NPV) of the anticipated additional tax savings, and compare this value with the observed enterprise value and the value of the takeover premium.

Relating the anticipated tax savings to the takeover premium allows us to ask our central question: who benefits from the tax savings associated with increased leverage? It is conventional to assume these accrue to the investors in the PE fund. However, access to leverage is available, on similar terms, to all the established PE sponsors. ${ }^{1}$ Furthermore, most large deals, of the sort we analyze in this paper, involve multiple competing bidders, since boards of public companies fear legal action from shareholders if they acquiesce to a single bid without testing whether other bidders would pay more. Often a potential LBO target will employ an investment bank to run a formal auction; sometimes the board of the target company will run a less formal auction process, involving multiple potential acquirers. Either way, provided the takeover process is reasonably competitive, and private equity sponsors have similar access to debt financing, then we would expect that ex ante predictable tax savings associated with the LBO - of the sort we estimate in this paper should be capitalized into the acquisition price. In this case, the party that benefits from the leverage in LBOs is likely to be the vendor - in our case the public equity investors - rather than the investors in the PE fund. As far as we are aware this is the first paper to make this important observation.

Testing this proposition is not straightforward. The takeover premium paid by private equity funds will reflect all sorts of unobservable expectations about revenue and margin growth, movements in market valuations, etc. as well as any potential tax benefits.

\footnotetext{
${ }^{1}$ The term private equity sponsor (or financial sponsor) is often used to refer to private equity firms - who sponsor potential buyouts involving other investors (in particular debt investors).
} 
So in general we would expect that the takeover premium should exceed our estimates of the anticipated tax savings. In cross-sectional regressions this is indeed what we find: on average the takeover premium is around twice the size of the capitalized tax savings. However, we find strong cross-sectional relationship between these two variables, which is consistent with the hypothesis that tax savings are captured by vendors via the takeover premium.

Our work builds on a similar analysis that Kaplan (1989) performed on a sample of LBOs from the earlier 1980s. ${ }^{2}$ Since that time, however, various factors have changed. Foremost, interest rates decreased by about 10 percentage points and conditions on debt became much more flexible. As we detail in Section 2, syndicated loan markets have developed significantly and institutional loans comprised the majority of LBO debt in recent years. Whereas in the 1980s leveraged loans were provided by banks and had fixed amortization schedules, institutional loans - mostly provided by credit and hedge funds have a bullet payment at maturity. During the term a borrower is only obliged to use a certain fraction of any excess cash to amortize debt. Clearly, this provides great flexibility to the borrower and the sponsor, as defaulting on debt is less likely in lower performing years. It further allows the PE sponsor to use higher levels of debt, as more cash is available for interest payments. The downside (at least for us) is that estimating future tax savings has become much less straightforward. The size of potential debt tax shields in every year is determined by the amount of interest expenses in that year, which depends on the level of outstanding debt principal. Interim amounts of debt are a function of initial LBO debt and a company's post-LBO performance. Consequently, in addition to obtaining detailed information on the size and terms of the various tranches of debt in the capital structure, one also has to make assumptions regarding a company's ability to generate excess cash and the fractions used to pay down principal.

\footnotetext{
${ }^{2}$ Our analysis focuses on the estimation of tax shields arising from higher interest expenses (i.e. the ex ante value of financial leverage in LBOs) and how these relate to the takeover premium. Kaplan (1989) further addresses the value of asset step-ups in his study. Shipper and Smith (1991) similarly examine the overall value of tax deductions with particular focus on the influence of individual tax environments for a sample of LBOs from 1982-86.
} 
In this paper, we run a number of simulations for each company in our sample, forecasting the level of excess cash flows in the years following the buyout. We base our projections on a company's most recent performance and incorporate various parameters to form different scenarios. Depending on a company's individual situation, we determine the size of the potential debt tax shield that could be used in any particular year, and apply instruments such as tax loss carry forwards and backwards for any remainder. We capitalize these post-LBO tax shields using the costs of each underlying debt tranche and measure the excess value over the (hypothetical) carried forward pre-LBO tax shields. Depending on underlying projections, we estimate that the 100 largest LBOs in our sample produced incremental corporate tax savings with an NPV of around $\$ 50$ billion.

Having estimated the capitalized incremental tax savings associated with the LBOs, we relate these to the takeover premia paid by PE sponsors. Traditionally in the literature takeover premia have been computed on equity values. However, we argue that measuring the takeover premium on the enterprise value is more relevant from an investor's perspective. To complete the transaction, the PE sponsor has to acquire the target company's shares (at a premium), but also needs to refinance the pre-LBO debt due to change of control covenants in a company's credit agreements. Consequently, it is the enterprise value of the target firm that defines the PE sponsor's cost basis, and the amount of capital that he needs to put on top of a company's enterprise value is of most relevance. As we show, depending on a target company's pre-LBO debt level, the premium measured in this way can differ significantly from the premium per equity share that has been used in papers focusing on conventional M\&A (see Eckbo (2009) for a literature review on takeover premia). We find a strong cross-sectional relationship between our measure of the capitalized tax benefits and the premium to initial enterprise value paid in the LBO transactions.

Our paper is relevant to those studies that have analyzed the sources of value creation (or destruction) achieved by private equity funds over their period of ownership (for example Guo, Hotchkiss and Song (2009)). Such studies have traditionally estimated the extent of any abnormal returns and attributed these to different levers, including additional tax savings. Our logic and findings, however, imply that anticipated tax savings 
associated with LBOs should be capitalized into the purchase price (and so accrue to the vendors), and only unanticipated tax effects can be used to explain returns to private equity investors over any particular holding period.

In addition to this, various interesting policy implications follow from our results. In particular, moves by national tax authorities to limit the tax deductibility of debt interest are likely to have their main impact on existing owners of assets, rather than private equity acquirers. Essentially, the potential benefits of highly leveraged transactions would be reduced, and this would be reflected in the price that private equity funds should be prepared to pay. It is worth noting that it is not certain that the actual amount of leverage employed by the private equity funds in their portfolio companies will necessarily change, given the option-like payoffs associated with the profit-share arrangements enjoyed by the executives working for private equity funds (see Axelson et al. (2010)). However, limitations on debt interest tax deductibility would reduce the competitive advantage that financial sponsors enjoy - in respect of financial engineering - over conventional corporate acquirers (who generally use much less debt). Consequently, it is likely that any such restrictions on the tax deductibility of interest expenses would reduce private equity sponsored deals as a proportion of total M\&A activity.

The remainder of the paper is structured as follows. In section two we give a short introduction into the characteristics of LBOs as well as some background on the leveraged finance market and its recent developments that are essential to understand our methodology. The third section describes our sample selection and the data we use, and illustrates the methodology we apply in our scenario-based approach. Section four contains the empirical results. The final section concludes.

\section{Leveraged Buyouts}

In the six years before the financial crisis LBOs increased significantly, both in number and average deal size. This was particularly the case for public-to-private takeovers in the U.S. As Table I shows, PE sponsors paid about $\$ 635$ billion in total to acquire the 259 companies that were taken private from 2003-08. The purchase price includes acquiring the 
debt and equity, as well as (not insignificant) transaction costs. If we focus on the equity component, the overall market capitalization of the bought-out companies prior to the takeover announcement was about $\$ 413$ billion and shareholders received immediate capital gains of $\$ 108$ billion in these public-to-private LBOs. This equates to a weighted average premium for shareholders of $26.2 \%$ compared to the pre-takeover stock market value of these companies.

This growth in LBO activity was mainly driven by three factors. First, the amount of funds raised by private equity investors had grown tremendously; see Figure I. Second, debt for leveraged transactions became more and more available. Third, the growth of club deals - involving multiple private equity sponsors - drove ever-larger LBOs and, hence, increased the average transaction value.

In this paper we focus on the largest 100 buyouts during the 2003-08 period. For each of these companies we obtain detailed accounting, financing and transaction data, most of which has to be hand collected. To give a feel for the data, we present summary information on the largest 25 deals in our sample in Table II.

\subsection{Characteristics and structure of leveraged buyouts}

LBOs involve the acquisition of a company by financial sponsors who aim to achieve at least a controlling stake in the target. In addition to the equity contribution of the private equity investor, LBOs are financed to a substantial extent with debt, which amplifies the final returns on equity. These funds are initially used to purchase the target's equity, to repay existing debt, as well as to pay transaction fees. We give an illustrative example of the sources and uses of funds in LBOs in Table III. The debt is provided by banks and institutional lenders as a structured package. Collateral for the loans is provided by the target's cash flows and assets. During their period of ownership, the PE investor tries to create value before exiting the investment by taking the company public or by selling to a strategic, or another financial, investor (see Kaplan and Strömberg (2008)). 


\subsection{Leveraged finance and changes in the debt capital markets}

The debt and its structure play an important role in LBOs, as it is one of the relevant drivers to maximize the final returns on the sponsor's equity investment. An LBO debt package consists of several debt tranches with different characteristics. These tranches mainly differ in seniority and collateralization, which results in different terms and margins. We give an example of the type of debt structure that was typical during our sample period in Table IV. In general, debt tranches can be divided into leveraged loan and high-yield notes or mezzanine tranches. The leveraged loan part usually consists of at least two tranches: a term loan facility and a revolving credit facility. Leveraged loans have a floating interest rate with a margin above a pre-defined base rate. One or more tranches of high-yield notes may be issued within several months after a successful LBO (bridge loans of up to one year are used to fill this gap). These notes can be either publicly listed or privately placed, and have usually a fixed-rate coupon (see Axelson et al. (2010) for evidence on LBO capital structures in both the U.S. and Europe).

Conditions and structures of leveraged loan tranches and high-yield notes changed significantly in the years before the financial crisis. Traditionally, the loan part of a typical LBO had a pre-agreed amortization schedule - usually on a straight-line basis - resulting in a full amortization over its term (so-called Term Loan A). Depending on its size, a loan was syndicated between several national commercial banks that retained a traditional focus on a company's fixed assets as collateral (asset-based lending). Due to the higher amount of fixed charges and over-collateralization, the total size of the loan was limited. In more recent years, drawing on the experience that few leveraged loans were held until maturity (but were refinanced after a couple of years at a company's exit), a structure that supported the amortization of a loan until maturity was no longer key. Furthermore, straight-line amortization shifted towards progressive schedules, which mimicked the projected free cash flows in the years after the LBO. This resulted in an increasing proportion of loans having minimal amortization (so-called Term Loan B), with single "bullet" repayments of principal at the end of the term. These structures allowed higher leverage to be supported by any given projected cash flow. 
While Term Loan A tranches were the most senior tranche in almost all LBOs until the early $2000 \mathrm{~s}$, more recently, and in $88 \%$ of all LBOs in our sample, Term Loan B tranches represent the core of the overall debt package. ${ }^{3}$ These loans oblige the borrower to use a certain portion of his annual excess cash flow for principal repayment. This agreement, called a cash sweep, gives the borrower more financial flexibility and reduces the risk of bankruptcy in low performing years. In estimating the tax benefits associated with the LBO, the projections of free-cash flow are critical, as they drive the speed of debt principal repayments and therefore the future projected interest expenses.

In addition to bank loans various other debt instruments are used, depending on the market conditions. In the high-yield notes segment so-called payment-in-kind (PIK) notes became more and more common until mid-2007, usually as the most junior tranche in an LBO debt package. PIK notes offer the borrower the choice to pay interest either at a certain rate in any year or to skip interest payments for one or more years and to pay them at a higher rate together with the principal at maturity. This form of debt gives the Private Equity investors the opportunity to further leverage their equity investment. In our sample $38 \%$ of all 2007 transactions involved a PIK tranche (compared to $27 \%$ in 2006 , 7\% in 2005 and $0 \%$ in the previous two years).

Various other changes, including new debt instruments such as second-lien tranches and covenant-lite loans emerged in recent years (see Miller and Chew (2008)). Some of these more recent inventions disappeared during the turmoil in credit markets, but are an important feature of the sample of deals that are analyzed in this paper. All these developments imply that it is increasingly complex to estimate the interest payments on

\footnotetext{
${ }^{3}$ These leveraged loans were increasingly demanded by institutional investors, such as credit funds and hedge funds. Most of the debt was then securitized and refinanced by issuing short and medium-term notes, or assetbacked commercial paper programs. Such institutional investors were more interested in an additional spread of 25-50 basis points than in regular amortization, which drove up the use of Term Loan B. Whereas in 2001 institutional investors provided $15 \%$ of all leveraged loans, by 2007 this fraction had increased to over $60 \%$, while the overall amount of leveraged loans more than tripled (see Acharya et al. (2007) on institutional investors and LBOs).
} 
debt and the evolution of the capital structure. Both these are needed to estimate the incremental tax savings associated with the LBOs.

\section{Sample and methodology}

\subsection{Sample data}

Our sample contains detailed information on the 100 largest public-to-private LBOs of U.S. companies listed on a U.S. stock exchange between 2003-08. The U.S. is the best market to investigate since it has by far the most public-to-private LBOs. Furthermore all transactions are in the same jurisdiction with identical market and regulatory circumstances, which avoids unobservable biases (in contrast to the European LBO market for example).

To identify LBO transactions we used Bureau van Dijk’s Zephyr M\&A Database. We cross checked the sample against the results of an identical query on Standard \& Poor's CapitalIQ database to make sure we have a comprehensive set of transactions. In total we identified 259 public-to-private LBOs during the period. The work involved in analyzing each transaction is considerable, and so we focus on the 100 largest transactions. As the criteria for size we chose the enterprise value observed in the transactions, consisting of the equity purchase price for outstanding shares and options plus the target's net debt. On this basis each LBO in our sample had an enterprise value in excess of $\$ 500$ million.

Table $\mathrm{V}$ provides some details about the sample. The table shows that total deal sizes increased between 2003-07 with $40 \%$ of the 100 largest deals taking place in 2007. 55 companies continued filing with the SEC due to a public bond offering; this allowed us to validate our scenarios for a part of our sample in early years after the LBO. The portion of deals with an amortizing bank loan (Term Loan A) tranche substantially decreased due to the substitution with institutional (Term Loan B) loans; moreover, high-yield notes with a PIK option, which are generally held by institutional investors, increased significantly in 2006-07. Buyouts in our sample were most common in the consumer discretionary industry, followed by the IT and the health care sectors.

Table VI shows details on the pre-LBO valuation of our sample companies based on the one-day premium. Prior to the announcement of an LBO our 100 companies had a 
combined market capitalization of $\$ 334$ billion, and a total enterprise value of $\$ 426$ billion. Net debt equaled $17.5 \%$ of the enterprise value (22 companies had a negative net debt position). On average, interest expenses were $16.0 \%$ of a company's last-twelve months (LTM) earnings before interest, taxes, depreciation and amortization (EBITDA), and 22.6\% of LTM EBITDA-Capex.

Detailed company data for our sample came from annual and quarterly reports filed with the U.S. Securities and Exchange Commission (SEC). We extracted information on debt levels and interest rates, tax details, performance data, etc. from the last three annual reports as well as the four quarterly reports prior to the LBO. For companies that continued filing with the SEC after the LBO we collected post-LBO data for controlling purposes as well. Data on each individual LBO structure came from proxy statements filed with the SEC, company reports following the transaction, and Reuters Loan Pricing Corporation. Beside the overall purchase price we collected details on the financing structure of each LBO including individual debt tranches with terms and pricings, the sponsor's equity contribution as well as transaction fees. Where available we also took actual management projections of future performance numbers such as EBITDA and Capex.

For interest payment calculations we use the three-month US\$ LIBOR which typically serves as the base rate for floating rate debt tranches. We obtained these numbers from the British Bankers' Association.

To calculate the effective premium of a final bid we used a company's stock price one day prior to the earliest public announcement of a possible takeover. This can either be the day prior to the final bid or a first bid (in case of multiple bids), or the day prior to the rumor of a possible LBO or the sale of the company. We collected these dates from the Zephyr database, which also tracks information on announcement and rumor activity prior to takeovers. To correct for possible leakage of news about intended takeovers in the market we also calculated the stock prices one month and two months before this earliest date, adjusted by the associated industry sub-index of the S\&P 500. We obtained the time series of stock prices from the Center for Research in Security Prices and the S\&P 500 subindices from Global Financial Data. 


\subsection{Methodology for calculating the tax benefits from $L B O s$}

The first main objective is to determine the expected NPV of future incremental tax shields resulting from higher interest payments. As mentioned before, this is not straightforward in the case of LBOs involving a number of debt tranches, with different terms and conditions, and finite holding periods.

The significant increase in a company's debt and, therefore, the value of higher tax shields is not permanent. Private equity investors aim - and are required by their lenders to free up cash and pay back LBO debt to reduce the default risk of a portfolio company. Therefore, the traditional permanent debt approach - whereby the leverage used at the time of the acquisition is assumed to persist into the future - would exaggerate the value of debt tax shields. Instead, we create a model that determines each company's debt and tax positions for every year following the LBO, and produce various scenarios for future incremental tax savings and their risk-adjusted NPVs. With respect to the holding period of a company, we follow a conservative estimation by modeling any incremental tax shields for 10 years following the LBO. A decade is the maximum term of any LBO's junior debt tranche, although in practice lenders would expect the level of indebtedness to return to more normal levels well before the maximum term of the loans, depending in part on the performance of the company (and therefore the extent of any cash sweep).

The most important variable in our model is the EBITDA of each company and its future development. As a basis for future scenarios we take the normalized LTM EBITDA of a company. Since PE investors are generally interested in companies with the potential to grow EBITDA we assume different growth rates for the following years. This growth can be either achieved by increasing sales and revenues (ideally without additional capital expenditures), or by margin improvements. The normalized LTM Capex level serves as a basis for future Capex estimations. In some of our scenarios we incorporate reductions in Capex as this is often the case after an LBO. To estimate future depreciation and 
amortization (D\&A) we maintain the LTM D\&A level adjusted by deferred tax expenses. In some scenarios, we use available management projections for these figures instead. ${ }^{4}$

Starting with the EBITDA we continue with two parallel computations for every year following the LBO. First we estimate each company's taxable income (TI) in order to obtain the current year's tax provision or benefit, the amount of tax losses carried backwards or forwards and, therefore, the resulting tax shield that can be used in any particular year. Second, we estimate the current year's free cash flow in order to determine the amount of principal debt repayment, using different assumptions about the extent of the cash sweep. Since the amount of principal debt repayment in every year determines the borrower's interest obligation in the following year, our computations have an iterative character. Our approach is similar in spirit to Shevlin (1990) and Graham (1996a, 1996b), although we use a variety of forecasts for future earnings growth (rather than simulations based upon past performance) in our scenarios. In general, at the time of the transaction, PE sponsors anticipate growth in earnings and our scenarios, which we detail in section 4.2., reflect this.

To calculate the TI we deduct tax-relevant D\&A as well as interest expenses for the current year, and adjust for potential carried-forward tax losses from previous years. In general, a negative TI (net operating loss) can offset tax payments from the previous two years and/or will result in a carried-forward tax loss that is available to shield tax obligations in future years.

To calculate the free cash flow we deduct projected capital expenditures and interest expenses from the EBITDA and either deduct tax payments or add a tax refund. A certain fraction of this free cash flow is then used to repay debt principal beginning with the most senior tranche. We also need to estimate the corporate tax rate of each company. Statutory and effective tax rates can differ significantly. ${ }^{5}$ Consequently, we estimate each company's individual tax rate based on the notes in its annual reports. In our calculations we use the

\footnotetext{
${ }^{4}$ We obtained EBITDA and Capex projections for 68 of our sample companies from the takeover documents for up to 6 years. The average company is expected to grow EBITDA at an annual compound rate of $10.9 \%$ ( $9.9 \%$ for the median, and $7.0 \%$ and $13.0 \%$ at the lower and upper quartile, respectively).

${ }^{5}$ This would be the case, for example, if a company generates substantial earnings overseas.
} 
average effective tax rate from the three fiscal years prior to the LBO after adjusting for tax losses carried forwards (backwards) from any previous year. This leads to a median effective tax rate of $36.6 \%$ and an average effective tax rate of $36.3 \%$. For comparison purposes, we also conduct our calculations with the U.S. federal tax rate of $35.0 \%$ for all companies in our sample.

The calculation of the present value of future tax shields under each scenario is performed as follows: First, we calculate the amount of interest expenses for every year after the LBO based on different input parameters. We then determine how much of these interest expenses can serve as a tax shield in any particular year and/or be offset against taxes paid in previous years. Any remaining tax shields are carried forward to subsequent years. Finally, we capitalize the individual fractions of all tax shielding interest expenses in every year using the interest rate of each underlying debt tranche, and multiply with the effective corporate tax rate.

To calculate the overall increase in the present value of debt tax shields we have to deduct those amounts that would have occurred anyway, i.e. if no LBO had taken place. We assume the average interest expenses over the previous three years is a reasonable estimate for future non-LBO interest expenses provided there was no increase in issued debt in a company's recent past; in such cases we use only the most recent amount of interest expenses as a projection. The present value of these hypothetical future interest expenses is then calculated by using the three-month US\$ LIBOR plus a margin according to the company's pre-LBO rating. Finally, we multiply the present values of these annual non-LBO tax shields with the effective corporate tax rate and sum up the positive differences of the LBO debt tax shields for every year.

We run eight different scenarios on our entire sample using various underlying assumptions. The most important input parameters that can differ, and influence the level of principal debt repayments, are growth rates of future EBITDA, initial reductions and future growth of Capex, and different portions of free cash flows being subject to the cash sweep provision. These scenarios are explained in more detail in section 4. 


\subsection{Methodology for calculating the takeover premium}

To test whether the anticipated debt tax shields from LBOs impact on the price paid for the company, we need to estimate the value of the takeover premium. Traditionally, the literature has focused on the equity premium - how much equity holders are paid relative to the market capitalization of the company prior to the bid. As mentioned earlier, there are different ways of defining the pre-bid share price, depending on whether rumors of potential bids start impacting on the market price. We use three different bases for determining the pre-bid equity value: the stock price one day prior to the earliest available public information to determine the premium, and the stock prices one month and two months before the earliest announcement date (adjusted by the associated S\&P 500 industry sub-index). As we will see in the next section, and in line with previous work on takeover premia, there is evidence that information leaks into the market, especially in the month prior to formal announcement (see Schwert (1996), Wright et al. (2007), Bargeron et al. (2008), Eckbo (2009)).

We also propose an alternative basis for measuring the premium, which we argue is more relevant for LBOs. When taking a public company private, PE sponsors focus on the enterprise value, rather than just the equity market capitalization of the company. This is because they will have to re-finance the existing debt, which becomes immediately due if there is a change of ownership or control. Refinancing a company's debt prior to maturity is likely to be associated with certain costs, such as a penalty for early amortization of loans or a call premium for issued bonds. However, investors who take over a public company do not have to pay a control premium on a company's debt. Therefore, acquiring the debt component of a company's enterprise value does involve some costs, but these are probably much lower than the control premium that must be paid to equity holders. Consequently, as we illustrate in the next section, the premium on enterprise value is in many cases

significantly different from the equity premium. In our regression analysis we focus on the premium measured relative to the overall enterprise value, and estimate the cross-sectional relationship with the NPV of the incremental tax savings. 


\section{Results}

\subsection{Sample characteristics}

Table VII examines the value characteristics and takeover premia of the LBOs in our sample. The enterprise values of the transactions, measured at the final bid prices, increased significantly between 2003-07; the mean transaction sizes in 2006 and 2007 are considerably in excess of the medians, reflecting a few very large transactions. Given the huge spate of LBOs in 2006 and 2007, the cumulative value of the 66 deals in those years represents about $80 \%$ of the overall sample value of $\$ 513.5$ billion (we control for this fact in our regressions). The EBITDA multiples of the enterprise values at premium increased between 2003-07 (with a small drop in 2005) and reached record levels in recent years. Interestingly, the median and mean EV to EBITDA multiple in 2008 still exceeded 10, despite the difficulties in the U.S. credit markets at that time.

As mentioned before, we calculate the premium relative to both the equity and the enterprise value for the one day, one-month and two-month (adjusted) periods prior to the earliest announcement date. The adjusted one- and two-month premia are significantly higher than the premia based on the day before the first public information of a possible takeover (as indicated by a paired t-test). This is consistent with rumors of possible bids starting to impact on market prices in the weeks before the first officially available information. The much higher percentage premia in 2003 are a result of lower equity valuations due to weak stock markets at that time. Figure II illustrates the relationship between the conventional premium per share and the premium on enterprise value. In some cases the difference is significant. For example, a $25 \%$ equity premium can relate into an EV premium from as low as $12 \%$ to as high as $31 \%$. Indeed, since some companies have a negative amount of net debt, i.e. more cash and short-term investments than debt on their balance sheets, the equity value can be higher than the enterprise value. Consequently, the percentage premium will be higher relative to a company's EV. The diagonal dotted line separates the companies with a negative amount of net debt.

Table VIII shows that the leverage - measured as a multiple of EBITDA - that was used to finance LBOs increased significantly until 2007. There are two major reasons for 
this. First, the increased supply of institutional debt led to ever-higher lending limits for senior loans as a multiple of a target's EBITDA. This is particularly remarkable since the effective interest rates for leveraged loans increased as well until mid-2007. To some extent this trend can be explained by the growth of second-lien loans and institutional loan tranches without fixed amortizations of debt principal: cash was increasingly available for interest payments and, hence, higher debt levels could be carried. Second, the supply of high-yield notes to already higher leveraged targets (with respect to higher levels of senior loans) remained relatively stable until 2007, accepting lending against ever more sensitive parts of a target's EBITDA. One reason for this is the increased supply of payment-in-kind notes that gave the borrower the option to avoid cash interest payments by issuing additional securities.

For the median company in our sample the interest expenses as a proportion of the pre-LBO EBITDA increased from $14.2 \%$ to $60.3 \%$ as a result of the LBO. This latter figure excludes interest on PIK tranches of debt; if this is included the proportion increases to 64.6\%. Relative to EBITDA-Capex interest expenses constituted $19.1 \%$ before the LBO, and increased to $82.2 \%$ in the first year after the LBO $(86.8 \%$ including interest payments on PIK tranches). These are remarkable changes to the capital structure, with significant implications for future tax savings. Figure III illustrates the change in the capital structure and interest obligations for the average company in our sample.

When looking at the percentage of the sponsors' equity contributions, one can see that these did not, on average, decrease as a result of increased levels of debt since the multiples of total deal values went up simultaneously. In other words PE sponsors were not able to additionally lever up their own equity contribution despite a higher availability of debt.

\subsection{Value of tax shields following our scenario-based approach}

Table IX shows our estimates of the NPV of the incremental future debt tax shields as

fractions of paid premia for different scenarios. We show results from eight scenarios with 
different underlying assumptions regarding the future excess cash flows of our sample companies and the portion of this cash used to repay debt principal.

The assumptions of scenario one result in amounts of excess cash flows at the higher end of what might be possible. All cash is then used in every year to repay debt principal. Hence, the amount of outstanding debt and implied interest expenses in future years decrease relatively quickly and the additional tax shields become comparably smaller. At the other extreme, in scenario eight we use assumptions resulting in lower excess cash flows in future years. Only the minimum of these amounts is then used to repay debt principal. Hence, the companies under this scenario have higher interest expenses, resulting in comparably higher additional tax shields. However, such a slow pace of debt repayment would likely result in covenant breaches of debt-to-EBITDA ratios in credit agreements, and PE sponsors would face substantial problems selling a company that remained so highly leveraged. Scenarios one and eight therefore put bounds on the reasonable estimates for the anticipated tax savings associated with the LBO.

The most likely scenarios, that approximate LBO sponsors' expectations, are probably towards the middle of our range of scenarios. In Figure IV we show the evolution of debt principal and the ratio of debt to EV (estimated as projected EBITDA times the EV/EBITDA multiple observed at entry) for scenarios 1, 4 and 8. In our regression analysis we focus on scenario 4 , which assumes a $5 \%$ expected growth rate for EBITDA, no change in capex relative to pre-LBO levels, a full sweep of excess cash to repay debt, and no interest payments on any PIK notes. Although we estimate the incremental tax savings for up to 10 years - which is clearly longer than the intended holding period for PE sponsors under scenario 4 by year 6 the ratio of debt to enterprise value has fallen to around $40 \%$, and so the bulk of the NPV of the incremental tax savings will have accrued by this stage.

Over the first two to three years the amounts of outstanding debt principal do not differ very much. In later years higher differences in interest payments are partly offset due to stronger capitalization effects. Thus, the numbers in Table IX vary in a limited range throughout all scenarios (this is visualized in Figure V). For the median company in our sample the present value of the additional tax shields is in the range of $42.3 \%$ to $59.3 \%$ of the one-day premium (in cash terms). Between $12 \%$ and $21 \%$ of the companies have new 
tax shields that exceed the value of the paid premium. Measuring the value of higher tax shields as a fraction of the one-month and two-month adjusted premia results in somewhat lower values: the present values of those tax shields compared to the adjusted premia are in the range of $34.8 \%$ to $48.4 \%$ for the median company. Only $4 \%$ to $13 \%$ of the companies in our sample have additional tax shields in excess of the adjusted paid premia. Relative to the pre-LBO enterprise values of our companies (calculated on the basis of the one day premia) the present value of these incremental tax shields is in the range of $7.8 \%$ to $11.1 \%$.

\subsection{Regression analysis of takeover premia}

In cash terms, the takeover premia in our sample average $\$ 767$ million (\$864 and $\$ 843$ million for the one-month and two-month adjusted premia) and the projected tax savings average \$400 million, using scenario 4. Whilst the size of the tax savings relative to the takeover premia are interesting in their own right, it is clearly important to test whether there is a cross-sectional relationship between the two variables. A positive relationship would be consistent with the hypothesis that investors appropriate a share of any tax benefits associated with increased leverage.

Table $\mathrm{X}$ presents the results of our regression analysis. The dependent variable is the takeover premium paid in the transaction, normalized by the pre-LBO enterprise value, measured one day, one month and two months before the first announcement. The main explanatory variable of interest is the capitalized value of the incremental tax shields, also measured relative to the pre-LBO enterprise value, following the increase in financial leverage. We focus initially on the estimates for the tax savings produced using scenario 4.

We also include the fraction of equity provided by the private equity fund. Our hypothesis is that private equity sponsors will tend to maximize the amount of debt they raise for a transaction - since they attempt to maximize the expected return on equity, given their option-like incentives. This amount will clearly depend upon the state of the leveraged finance markets, as well as any particular features of the target company. We capture these market and company-specific effects using time and industry fixed effects. For those deals where the amount of equity invested is high (allowing for fixed effects) we test whether this 
reflects aggressive bidding by the private equity fund - in which case the impact on the premium would be positive. We also include two dummy variables to reflect the financial structure of the deal: whether there is amortizing Term Loan A in the capital structure, and whether (non-amortizing) PIK debt is used. We would expect the main impact of the use (or not) of Term Loan A would be reflected in the tax shield variable - since having Term Loan A reduces the quantum of debt and so tends to reduce the tax shields - but it is possible that there might be an independent effect on the premium if transaction prices are influenced by leverage (as suggested by Axelson et al. (2010)). We therefore expect the coefficient on Term Loan A to be negative, and the coefficient on the PIK dummy to be positive.

Finally, we include a dummy variable that captures whether the price that received final shareholder approval was equal to, or above, the initial bid. This variable attempts to capture the negotiating strength of the target's board - resulting from rival bidders and/or the board of directors refusing to accept an initial bid - which would be expected to impact on the ability of the shareholders to appropriate the tax benefits. In practice it is difficult to measure how competitive the bidding process is, since the board of directors can always threaten to open the bid process to another bidder - under so-called "go-shop" agreements and so a good board of directors will negotiate hard even with a sole bidder. Nonetheless, we include this variable to see if we can identify any such effects.

We first present the results for the simple uni-variate regression. Irrespective of the date at which we measure the premium we find a very strong and positive cross-sectional relationship between the present value of the future incremental tax shields and the premium paid. The estimated coefficient varies from 0.74 (for the premium measured one day before announcement) to 1.23 (one month before) to 1.68 (two months before). This increase reflects the information leakage observed earlier, whereby share prices drift upwards in the period before the formal announcement. Although many other factors - such as the anticipated (but unobservable) efficiency improvements etc. - will impact on the premium that private equity funds are prepared to pay, there is strong evidence that the estimated tax benefits have a strong influence. 
These results continue to hold when we include additional control variables and when we add year and industry fixed effects. To gauge the economic significance of the impact of the tax savings on the premium, at the sample mean a one-standard deviation increase in the estimated tax benefits is associated with an increase in the premium paid from $22.4 \%$ to $28.8 \%$ (using the one-month regression including fixed effects).

We also find evidence that higher equity contributions by the private equity sponsor are associated with higher premia. This is consistent with the hypothesis that once the private equity funds have borrowed the maximum amount of debt, the competitiveness of the bidding process will be reflected in the equity check they are prepared to write. At the sample mean, a one-standard deviation increase in the equity contribution is associated with an increase in the premium from $22.4 \%$ to $28.2 \%$, again using the one-month regression including fixed effects.

In terms of the capital structure variables, we find evidence that the use of amortizing Term Loan A debt reduces takeover premia (over and above any effect on the interest tax shield). However, the significance of this effect varies according to how we measure the premium. On the other hand, we find almost no significant effect in any of the regressions of our dummy variable for the use of PIK debt. We also do not find that our measure of the competitiveness of the bid process has any effect, although we suspect this is because all bid processes in public-to-private deals in the U.S. involve the board seeking competitive bids, or testing the proposed bid against the market (using recent transactions and fair value opinions from bankers).

\subsection{Robustness checks}

We run various checks to verify the robustness of these findings. The results in the previous section were based on the input parameters from scenario 4 to generate the incremental tax savings. Table XI shows the coefficients and t-values of the same regressions (including year and industry fixed effects) based on the tax shields under all 8 scenarios. Coefficients vary within a limited range. For the one-day premium coefficients are in the range 0.74 to 0.94. For the one-month (two-month) adjusted premia coefficients range from 1.06 to 1.24 
(1.35 to 1.57). Under all scenarios the incremental tax shields are again significant at the 99\% level in these cross-sectional regressions.

An important part of our analysis involves estimating the effective marginal corporate tax rate for our sample of LBOs. We next test the sensitivity of our results to these estimates by substituting the statutory $35 \%$ federal tax rate for all companies. The results from re-running the regressions with the tax shields estimated on this basis are presented in Table XII. In all cases, the estimated coefficients on the tax shield increase slightly, which is consistent with the fact that we estimated the average effective tax rate to be slightly above $35 \%$. The statistical significance remains at the same high level.

\section{Conclusions}

This paper estimates the ex ante value of financial leverage produced by the 100 largest U.S. public-to-private leveraged buyouts over the period 2003-08. The capital structures of these transactions are complex and differ significantly from those observed in earlier periods. Many of the transactions occurred in the years just before the financial crisis when debt was abundant and available on very favorable terms, resulting in the very high leverage we observe in many of the deals in our sample. Prior to their purchase by private equity funds, the ratio of net debt to EBITDA of our sample companies averaged 1.5; the LBO transactions increased this ratio, on average, to 7.6. In terms of interest payments, these rose from an average of $22.6 \%$ of free cash flow (EBITDA-Capex) before the LBO to $85.4 \%$ in the first year after the LBO. However, the capital structure can change rapidly due to the impact of cash-sweep provisions in typical loan contracts, and so estimating the anticipated tax savings is complex. We model the future cash flows and capital structures under a variety of scenarios to derive a range of estimates for the net present value of the incremental tax shields generated by the LBOs. For these 100 largest transactions, the tax savings totaled around $\$ 50$ billion, which explains, in part, the political attention that LBOs have been attracting in many countries in recent years.

Since most private equity funds are able to leverage deals, and because the typical public-to-private deal involves competition between multiple bidders, we conjecture that 
these tax benefits should largely accrue to the vendors of the companies, i.e. the public shareholders, via the premium that is paid to them. To test this hypothesis we estimate cross-sectional regressions relating the premium to the capitalized tax savings. Since private equity funds have to both acquire the equity and refinance the debt in the target companies, we argue that the premium should be measured relative to the enterprise value. Taking account of both equity and debt is important, as no takeover premium is required to redeem the debt. This is in contrast to existing literature, which has focused on the premium paid to equity holders. Clearly, the premium that private equity funds will be prepared to pay will not only reflect the anticipated tax savings but also the unobservable expected efficiency improvements and changes in market valuation. On average we find that the present value of additional future tax shields that result from the substantial increase in a company's debt level and interest expenses constitute around $50 \%$ of the premium paid. We also find a strong, positive cross-sectional relationship between our estimated tax savings and the takeover premium. These results are consistent with the hypothesis that vendors appropriate much of the tax savings resulting from LBOs.

Consequently, we argue that tax savings associated with financial engineering are unlikely to be a source of value creation for private equity investors. This is in sharp contrast to the commonly expressed view that private equity funds returns are largely derived at the expense of taxpayers. Of course, these highly leveraged structures may have other beneficial effects that could accrue to investors, such as beneficial incentive effects by reducing free cash flow, or by sharpening incentives for managers more generally. Also, given that the debt in LBOs is pushed into the portfolio companies on a non-recourse basis, LBOs creates leveraged equity investment opportunities for investors that might be difficult to imitate. And the option-like remuneration of private equity fund executives - through their carried interests in the funds - means that they have incentives to increase risk and expected equity returns through using leverage. So even if governments restricted the tax benefits associated with debt, as some have recently done, it is likely that private equity buyouts would still be leveraged. The main impacts of a restriction on interest deductibility would, we argue, be to reduce an important advantage enjoyed by private equity funds 
when they bid against potential corporate acquirers, and, more significantly, to reduce the value of all companies that are potential targets for LBOs.

\section{References}

Acharya, Viral, Julian Franks, and Henri Servaes, 2007, Private Equity: Boom and Bust?, Journal of Applied Corporate Finance, 19 (4).

Axelson, Ulf, Tim Jenkinson, Per Strömberg, and Michael S. Weisbach, 2010, Borrow cheap, buy high? The determinants of leverage and pricing in buyouts, NBER working paper.

Bargeron, Leonce L., Frederik P. Schlingemann, René M. Stulz, and Chad J. Zutter, 2008, Why do private acquirers pay so little compared to public acquirers?, Journal of Financial Economics, 89, 375-390.

Eckbo, B. Espen, 2009, Bidding Strategies and Takeover Premiums: A Review, Journal of Corporate Finance, 15 (1), 149-178.

Graham, John R., 1996a, Debt and the Marginal Tax Rate, Journal of Financial Economics, 41, 41-73.

Graham, John R., 1996b, Proxies for the Corporate Marginal Tax Rate, Journal of Financial Economics, 42, 187-221.

Graham, John R., 2000, How Big Are the Tax Benefits of Debt?, Journal of Finance, 55, 1901-1941.

Graham, John R., 2001, Estimating the Tax Benefits of Debt, Journal of Applied Corporate Finance, 14, 42-54.

Guo, Shourun, Edith S. Hotchkiss, and Weihong Song, 2009, Do Buyouts (Still) Create Value?, Journal of Finance, Forthcoming. 
Jensen, Michael C., 1986, Agency Costs of Free Cash Flow, Corporate Finance and Takeovers, American Economic Review, 67 (5), 61-74.

Jensen, Michael C., 1989, Eclipse of the Public Corporation, Harvard Business Review, 76 (2), 323-335.

Kaplan, Steven. N., 1989, Management Buyouts: Evidence on Taxes as a Source of Value, Journal of Finance, 44 (3), 611-632.

Kaplan, Steven N., and Per Strömberg, 2008, Leveraged Buyouts and Private Equity, Journal of Economic Perspectives, 22 (4).

Miller, Steven, and William Chew, 2009, A Guide to the Loan Market, Standard \& Poor's.

Schipper, Katherine, and Abbie Smith, 1991, Effects of Management Buyouts on Corporate Interest and Depreciation Tax Deductions, Journal of Law and Economics, 34 (2), 295-341.

Schwert, G. William, 1996, Markup Pricing in Mergers and Acquisitions, Journal of Financial Economics, 41, 153-192.

Shevlin, Terry, 1990, Estimating Corporate Marginal Tax Rates with Asymetric Tax Treatment of Gains and Losses, Journal of the American Taxation Association, 11, 51-67.

Wright, Mike, Luc Renneboog, Tomas Simons, and Louise Scholes, 2006, Leveraged Buyouts in the U.K. and Continental Europe: Retrospect and Prospect, Journal of Applied Corporate Finance, 18 (3), 38-55. 


\section{Table I - Public-to-private leveraged buyouts in the U.S.}

This table shows the leveraged buyout activity in the U.S. public market between 2003 and 2008. While the number of transactions from 2003-07 has multiplied by the factor 3.2, the average deal value has increased by a factor of 15.5 and the total value of all deals has increased by a factor of 49.5. Following the difficulties in the sub-prime mortgage market in mid-2007 and the drop in demand for securitized debt, LBO activity in 2008 has decreased to $2004 / 05$ levels.

\begin{tabular}{lrrrrrrr}
\hline & $\mathbf{2 0 0 3}$ & $\mathbf{2 0 0 4}$ & $\mathbf{2 0 0 5}$ & $\mathbf{2 0 0 6}$ & $\mathbf{2 0 0 7}$ & $\mathbf{2 0 0 8}$ & $\mathbf{2 0 0 3 - 2 0 0 8}$ \\
\hline U.S. Public-to-Private LBO & 22 & 27 & 43 & 69 & 70 & 28 & 259 \\
Total Deal Value (\$mn) & 6,292 & 27,446 & 55,066 & 199,442 & 311,178 & 36,018 & 635,442 \\
Average Deal Value (\$mn) & 286 & 1,017 & 1,281 & 2,890 & 4,445 & 1,286 & 2,453 \\
\hline
\end{tabular}

Source: Bureau van Dijk, Zephyr Global M\&A Database. 


\section{Table II - The 25 largest leveraged buyouts by enterprise value}

This table shows the 25 largest leveraged buyouts in our sample according to their enterprise value. The equity purchase price at premium is the value of all equity claims at the final bid price. Outstanding net debt presents the latest available information about each company's debt minus cash and short-term investments prior to the closing of the transaction; these numbers come from the most recent annual or quarterly report or the first post-LBO report in case of an ongoing filing with the SEC. Combined, these numbers determine each company's enterprise value at final bid. The total of all enterprise values of these 25 LBOs is approximately $\$ 380$ billion. The equity from the private equity sponsor stands for the amount of capital provided by private equity funds. The final column shows the percentage of this equity injection relative to the enterprise value.

\begin{tabular}{|c|c|c|c|c|c|c|c|}
\hline No & Target Company & Private Equity Spons ors & Final Bid Date & $\begin{array}{c}\text { Enterprise Value at } \\
\text { Premium(1) }\end{array}$ & $\begin{array}{l}\text { Equity Purchace } \\
\text { Price at Premium }\end{array}$ & $\begin{array}{l}\text { Private Equity } \\
\text { Injection }(2)\end{array}$ & $\begin{array}{l}\text { Private Equity } \\
\text { Fraction }\end{array}$ \\
\hline 1 & TXU Corporation & Goldman Sachs, KKR, TPG, etc. & $02 / 26 / 2007$ & 46,566 & 32,432 & 8,300 & $17.8 \%$ \\
\hline 2 & HCA Inc. & Bain Capital, KKR, etc. & $07 / 24 / 2006$ & 32,081 & 21,279 & 4,792 & $14.9 \%$ \\
\hline 3 & Harrah's Entertainment Inc. & Apollo, TPG, etc. & $12 / 19 / 2006$ & 28,930 & 17,199 & 6,079 & $21.0 \%$ \\
\hline 4 & First Data Corporation & $K K R$ & $04 / 02 / 2007$ & 27,730 & 26,319 & 7,232 & $26.1 \%$ \\
\hline 5 & ALLTEL Corporation & Goldman Sachs, TPG & $05 / 21 / 2007$ & 26,874 & 24,994 & 4,600 & $17.1 \%$ \\
\hline 6 & Hilton Hotels Corporation & Blackstone & $07 / 03 / 2007$ & 26,623 & 20,616 & 5,700 & $21.4 \%$ \\
\hline 7 & Kinder Morgan Inc. & Carlyle, Goldman Sachs, etc. & $08 / 28 / 2006$ & 24,783 & 14,590 & 7,831 & $31.6 \%$ \\
\hline 8 & Clear Channel Comm. Inc. & Bain Capital, THLee & $05 / 14 / 2008$ & 23,103 & 17,999 & 3,000 & $13.0 \%$ \\
\hline 9 & Freescale Semiconductor Inc. & Blackstone, Carlyle, Permira, & $09 / 15 / 2006$ & 15,520 & 17,608 & 7,150 & $46.1 \%$ \\
\hline 10 & Univision Comm. Inc. & $\begin{array}{l}\text { Madison Dearborn, Providence, } \\
\text { Saban Capital, TPG, THLee }\end{array}$ & $06 / 27 / 2006$ & 13,394 & 12,326 & 3,900 & $29.1 \%$ \\
\hline 11 & Biomet Inc. & $\begin{array}{l}\text { Blackstone, Goldman Sachs, } \\
K K R, T P G\end{array}$ & $06 / 07 / 2007$ & 13,234 & 13,383 & 5,387 & $40.7 \%$ \\
\hline 12 & SunGard Data Sys tems Inc. & $\begin{array}{l}\text { Bain Capital, Blackstone, KKR, } \\
\text { Providence, Silver Lake, TPG }\end{array}$ & $03 / 28 / 2005$ & 11,037 & 11,043 & 3,604 & $32.7 \%$ \\
\hline 13 & Realogy Corporation & Apollo & $12 / 17 / 2006$ & 8,979 & 6,685 & 2,001 & $22.3 \%$ \\
\hline 14 & Station Casinos & Fertitta Colony & $02 / 25 / 2007$ & 8,949 & 5,322 & 3,470 & $38.8 \%$ \\
\hline 15 & Aramark Corporation & $\begin{array}{l}\text { Goldman Sachs, THLee, } \\
\text { Warburg Pincus, etc. }\end{array}$ & $08 / 08 / 2006$ & 8,206 & 6,237 & 2,048 & $25.0 \%$ \\
\hline 16 & Puget Energy Inc. & Macquarie, etc. & $10 / 26 / 2007$ & 7,528 & 3,923 & 3,222 & $42.8 \%$ \\
\hline 17 & Dollar General Corporation & Goldman Sachs, KKR & $03 / 12 / 2007$ & 7,052 & 7,016 & 2,770 & $39.3 \%$ \\
\hline 18 & Avaya Inc. & Silver Lake, TPG & $06 / 04 / 2007$ & 6,985 & 8,258 & 2,400 & $34.4 \%$ \\
\hline 19 & CDW Corporation & Madison Dearborn, Providence & $05 / 29 / 2007$ & 6,713 & 7,293 & 2,403 & $35.8 \%$ \\
\hline 20 & Toys R Us Inc. & Bain Capital, KKR, Vornado & $03 / 18 / 2005$ & 6,658 & 6,084 & 1,300 & $19.5 \%$ \\
\hline 21 & HCR Manor Care Inc. & Carlyle & $07 / 02 / 2007$ & 6,230 & 5,401 & 1,300 & $20.9 \%$ \\
\hline 22 & Nuveen Investments Inc. & Madison Dearborn, etc. & $06 / 20 / 2007$ & 6,125 & 5,769 & 2,800 & $45.7 \%$ \\
\hline 23 & Michaels Stores Inc. & Bain Capital, Blackstone & $06 / 30 / 2006$ & 5,709 & 6,025 & 1,700 & $29.8 \%$ \\
\hline 24 & ServiceMas ter Company & Clayton, Dubilier \& Rice, etc. & $03 / 19 / 2007$ & 5,100 & 4,753 & 1,431 & $28.1 \%$ \\
\hline 25 & Sabre Holdings Corporation & Silver Lake, TPG & $12 / 12 / 2006$ & 5,062 & 4,503 & 1,386 & $27.4 \%$ \\
\hline
\end{tabular}

All values in million $\$$.

(1) The enterprise value does not include transaction fees and expenses.

(2) Private equity includes the management rollover in most cases.

Source: own sample data and calculations. 


\section{Table III - Illustrative sources and uses of funds scheme}

This table shows a typical "sources and uses of funds" scheme that is part of each LBO structuring process. This example comes from the LBO of HCA Inc. in 2006. The right-hand side lists the amounts of capital needed to complete the takeover. Typical positions are the purchase price of target's equity, the rollover equity by the retained management, the repayment of existing debt, as well as the costs resulting from the transaction. In this example a portion of target's existing debt is retained and listed on both sides. The lefthand side shows the sources of capital to fund the takeover. Beside multiple layers of debt, equity from the private equity investors, the rolled-over management stake, as well as cash at hand of target (in this case dividends from a subsidiary) are typical positions.

\begin{tabular}{|c|c|c|c|}
\hline Sources of Funds & $\$ \mathbf{m n}$ & Us es of Funds & $\$ \mathrm{mn}$ \\
\hline Senior Secured Credit Facilities & & Equity Purchase Price & 20,214 \\
\hline Asset Based Revolving Credit Facility & 1,750 & Rollover Equity & 1,065 \\
\hline Revolving Credit Facility & 188 & Repayment of existing Indebtness & 3,714 \\
\hline Term Loan A Facility & 2,750 & Retained existing Secured Indebtness & 230 \\
\hline Term Loan B Facility & 8,800 & Retained existing Unsecured Indebtness & 7,473 \\
\hline European Term Loan Facility & 1,250 & Transaction Costs & 776 \\
\hline New Notes & 5,700 & & \\
\hline Retained existing Secured Indebtness & 230 & & \\
\hline Retained existing Unsecured Indebtness & 7,473 & & \\
\hline Equity Contribution & 3,901 & & \\
\hline Rollover Equity & 1,065 & & \\
\hline HCI Dividend & 365 & & \\
\hline Total Sources of Funds & $\overline{33,472}$ & Total Uses of Funds & 33,472 \\
\hline
\end{tabular}

Source: Securities and Exchange Commission. 


\section{Table IV - Illustrative LBO debt package}

This table shows the debt package of the LBO of HCA Inc. The overall debt is divided into 5 tranches of firstlien secured loans and 3 tranches of second-lien secured notes. A fraction of the pre-LBO debt is retained after the takeover. The tranches in this package have subsequent claims regarding interest and principal payments and collateral, which results in different terms and margins. The two revolving credit facilities require fees on undrawn amounts and provide certain Letter of Credits and Swingline borrowings. The second revolver also offers partial drawings in different currencies. The term loan A has a pre-defined progressive quarterly amortization schedule. The two B tranches require amortization of 25 basis points (bps) per quarter and the payment of $50 \%$ of the defined excess cash flows of the borrower, with the remainder payable at maturity. All first-lien facilities include a performance pricing which reduces margins and excess cash payments once the total debt to EBITDA ratio drops below certain levels. The 3 notes tranches have a secondlien claim against the company's assets. Whereas the first two notes tranches require interest payments in cash, the $3^{\text {rd }}$ tranche gives the borrower the option to skip interest payments in the first 5 years until maturity.

\begin{tabular}{|c|c|c|c|c|c|c|}
\hline Debt Tranche & $\begin{array}{c}\text { Size } \\
\text { (in \$mm) }\end{array}$ & $\begin{array}{c}\text { Term } \\
\text { (in years) }\end{array}$ & $\begin{array}{c}\text { Interest } \\
\text { Base Rate }\end{array}$ & $\begin{array}{l}\text { Margin } \\
\text { (in bps) }\end{array}$ & $\begin{array}{l}\text { Commitment } \\
\text { Fee (in bps) }\end{array}$ & $\begin{array}{l}\text { EBITDA } \\
\text { Multiple }\end{array}$ \\
\hline Senior Secured Asset Based Revolving Credit Facility & 2,000 & 6 & Libor & 175.0 & 37.5 & 0.5 \\
\hline Senior Secured Revolving Credit Facility & 2,000 & 6 & Libor & 250.0 & 50.0 & 0.5 \\
\hline Senior Secured Term Loan A & 2,750 & 6 & Libor & 250.0 & & 0.7 \\
\hline Senior Secured Term Loan B & 8,800 & 7 & Libor & 275.0 & & 2.2 \\
\hline Senior Secured European Term Loan B & 1,320 & 7 & Euribor & 250.0 & & 0.3 \\
\hline Total Senior Secured First Lien Debt (new) & 16,870 & & & & & 4.2 \\
\hline Senior Secured Second Lien Cash-Pay Notes & 1,000 & 8 & - & 912.5 & & 0.2 \\
\hline Senior Secured Second Lien Cash-Pay Notes & 3,200 & 10 & - & 925.0 & & 0.8 \\
\hline Senior Secured Second Lien Toggle Notes & 1,500 & 10 & - & 962.5 & & 0.4 \\
\hline Total Senior Secured Second Lien Debt & 5,700 & & & & & 1.4 \\
\hline Total LBO Debt Package & 22,570 & & & & & 5.6 \\
\hline Retained Senior Secured Debt & 445 & & & & & 0.1 \\
\hline Retained Senior Unsecured Notes & 7,523 & & & & & 1.8 \\
\hline Total Debt after the LBO & 30,093 & & & & & 7.5 \\
\hline
\end{tabular}

Additional Information per Tranche:

1) Letter of Credit: $\$ 200 \mathrm{~m}$; Swingline: $\$ 100 \mathrm{~m}$; Performance Pricing

2) Letter of Credit: \$500m; Swingline: \$200m; Multi-Currency: \$400m; Performance Pricing

3) Amortization: 8 Quarter á $\$ 28.125 \mathrm{~m}, 8$ Quarter á $\$ 56.25 \mathrm{~m}, 4$ Quarter á $\$ 112.5 \mathrm{~m}, 3$ Quarter á 281.25m, 1 Quarter á $\$ 781.25 \mathrm{~m}$; Performance Pricing

4) Amortization: 27 Quarter á \$22m, 1 Quarter á \$8,206m; 50\% Excess Cash flow; Performance Pricing

5) 27 Quarter á $€ 2.5 \mathrm{~m}, 1$ Quarter á $€ 932.5 \mathrm{~m} ; 50 \%$ Excess Cash flow; Performance Pricing

6) Payment-In-Kind Option during the first 5 Years

7) Maximum Amount of Debt (the Senior Secured Revolving Credit Facility was only partially drawn at closing)

8) Primarily Capital Leases, effective Interest Rate of $6.7 \%$

9) Effective Interest Rate of $7.3 \%$

Source: Securities and Exchange Commission, Reuters Loan Pricing Corporation, Bloomberg. 


\section{Table V - Sample distribution}

This table shows the distribution of deals over time. Some targets continue filing with the SEC because of a public bond offering. For certain deals management projections are available. Term loan A tranches refer to an amortizing senior secured loan tranche. Payment-in-kind tranches give the borrower the option to choose between interest payments in time or at maturity at a slightly higher rate. The industry classification follows the Global Industry Classification Standard by S\&P and Morgan Stanley.

Panel A: Deals and Characteristics.

\begin{tabular}{lrrrrrrr}
\hline & $\mathbf{2 0 0 3}$ & $\mathbf{2 0 0 4}$ & $\mathbf{2 0 0 5}$ & $\mathbf{2 0 0 6}$ & $\mathbf{2 0 0 7}$ & $\mathbf{2 0 0 8}$ & $\mathbf{2 0 0 3 - 2 0 0 8}$ \\
\hline Number of Deals & 4 & 10 & 14 & 26 & 40 & 6 & 100 \\
& & & & & & & \\
Ongoing filings with the SEC & 4 & 5 & 8 & 20 & 17 & 1 & 55 \\
Financial Projections & 1 & 6 & 10 & 14 & 32 & 5 & 68 \\
Term Loan A Tranche & - & 2 & 1 & 2 & 5 & 2 & 12 \\
Payment-In-Kind Tranche & - & - & 1 & 7 & 15 & 1 & 24 \\
\hline
\end{tabular}

Panel B: Industry Classification of LBO Targets.

\begin{tabular}{|c|c|c|c|c|c|c|c|c|}
\hline Indus try & GICS & 2003 & 2004 & 2005 & 2006 & 2007 & 2008 & 2003-2008 \\
\hline Energy & 10 & - & - & - & 2 & - & - & 2 \\
\hline Materials & 15 & - & - & 1 & 2 & 1 & - & 4 \\
\hline Indus trials & 20 & 1 & - & - & 4 & 5 & 1 & 11 \\
\hline Cons umer Dis cretionary & 25 & 2 & 5 & 5 & 10 & 12 & 2 & 36 \\
\hline Cons umer Staples & 30 & - & 1 & - & - & 1 & - & 2 \\
\hline Health Care & 35 & 1 & 3 & 1 & 2 & 8 & 1 & 16 \\
\hline Financials & 40 & - & - & 1 & 1 & 3 & - & 5 \\
\hline Information Technology & 45 & - & - & 6 & 5 & 6 & 2 & 19 \\
\hline Telecommunications Services & 50 & - & 1 & - & - & 1 & - & 2 \\
\hline Utilities & 55 & - & - & - & - & 3 & - & 3 \\
\hline
\end{tabular}

Source: own sample data and calculations. 


\section{Table VI - Value characteristics of targets prior to the LBO}

This table shows the value characteristics of our sample companies prior to the LBO. The enterprise value includes a target company's equity value plus debt minus cash and short-term investments. The equity value is based on a company's market capitalization one day before the final bid price (alternatively, one day before the first bid or rumour in case of multiple events). EBITDA, Capex and Interest Expenses are normalized lasttwelve months numbers prior to the agreement of the transaction.

\begin{tabular}{|c|c|c|c|c|c|c|c|c|}
\hline & & 2003 & 2004 & 2005 & 2006 & 2007 & 2008 & 2003-2008 \\
\hline Number of Deals & & 4 & 10 & 14 & 26 & 40 & 6 & 100 \\
\hline \multirow[t]{3}{*}{ Enterprise Value (\$mn) } & Total & 2,556 & 19,167 & 29,760 & 144,876 & 204,633 & 25,324 & 425,893 \\
\hline & Median & 621 & 1,352 & 999 & 2,258 & 2,051 & 1,123 & 1,519 \\
\hline & Mean & 639 & 1,917 & 2,126 & 5,572 & 5,116 & 4,221 & 4,259 \\
\hline \multirow[t]{3}{*}{ Equity Value (\$mn) } & Total & 1,217 & 13,534 & 27,821 & 103,979 & 167,547 & 19,435 & 333,983 \\
\hline & Median & 248 & 1,156 & 1,030 & 1,543 & 1,560 & 861 & 1,262 \\
\hline & Mean & 304 & 1,353 & 1,987 & 3,999 & 4,189 & 3,239 & 3,340 \\
\hline \multirow[t]{4}{*}{ Percentage of Net Debt } & Median & $55 \%$ & $26 \%$ & $3 \%$ & $20 \%$ & $11 \%$ & $13 \%$ & $17.4 \%$ \\
\hline & Mean & $51 \%$ & $27 \%$ & $3 \%$ & $19 \%$ & $17 \%$ & $15 \%$ & $17.5 \%$ \\
\hline & Min & $24 \%$ & $3 \%$ & $-54 \%$ & $-34 \%$ & $-25 \%$ & $-6 \%$ & $-53.8 \%$ \\
\hline & Max & $70 \%$ & $45 \%$ & $62 \%$ & $53 \%$ & $63 \%$ & $46 \%$ & $70.1 \%$ \\
\hline \multirow{2}{*}{ Enterprise Value / EBITDA } & Median & 5.4 & 8.7 & 7.8 & 8.5 & 9.6 & 7.6 & 8.7 \\
\hline & Mean & 5.6 & 8.3 & 8.4 & 8.5 & 10.2 & 8.0 & 9.0 \\
\hline \multirow[t]{4}{*}{ Net Debt / EBITDA } & Median & 3.0 & 1.7 & 0.4 & 1.5 & 1.4 & 1.0 & 1.4 \\
\hline & Mean & 2.8 & 2.3 & 0.6 & 1.7 & 1.6 & 1.3 & 1.5 \\
\hline & Min & 1.5 & 0.2 & -4.7 & -3.0 & -1.8 & -0.3 & -4.7 \\
\hline & Max & 3.6 & 5.0 & 10.7 & 5.1 & 7.2 & 3.5 & 10.7 \\
\hline \multirow[t]{2}{*}{ Interest Expenses / EBITDA } & Median & $32.9 \%$ & $23.9 \%$ & $4.5 \%$ & $14.9 \%$ & $13.9 \%$ & $5.3 \%$ & $14.2 \%$ \\
\hline & Mean & $28.1 \%$ & $26.6 \%$ & $14.2 \%$ & $15.5 \%$ & $15.4 \%$ & $8.4 \%$ & $16.0 \%$ \\
\hline \multirow[t]{2}{*}{ Interest Expenses / EBITDA-Capex } & Median & $43.3 \%$ & $34.9 \%$ & $5.7 \%$ & $22.0 \%$ & $18.1 \%$ & $10.7 \%$ & $19.1 \%$ \\
\hline & Mean & $36.8 \%$ & $36.3 \%$ & $17.6 \%$ & $21.3 \%$ & $23.3 \%$ & $11.8 \%$ & $22.6 \%$ \\
\hline
\end{tabular}

Source: own sample data and calculations. 


\section{Table VII - Value characteristics of targets at the final bid price}

This table shows the value characteristics of our sample companies at the final bid price. The enterprise value includes a target company's equity value plus debt minus cash and short-term investments. The equity value is based on a company's market capitalization at the final bid price. EBITDA is the normalized last-twelve months number prior to the agreement of the transaction. The one-day, adjusted one-month and adjusted twomonths premia are on a percentage basis relative to a company's pre-LBO equity and enterprise values. The premium is the difference between the final bid and the stock price one day prior to the earliest announcement of a takeover or a sale. The one-month (two-month) adjusted premia are calculated based on the stock price one month (two months) prior to that date adjusted by the change in the associated industry sub-index of the S\&P 500 .

\begin{tabular}{|c|c|c|c|c|c|c|c|c|}
\hline & & 2003 & 2004 & 2005 & 2006 & 2007 & 2008 & 2003-2008 \\
\hline Number of Deals & & 4 & 10 & 14 & 26 & 40 & 6 & 100 \\
\hline \multirow[t]{3}{*}{ Enterprise Value at Premium (\$mn) } & Total & 3,053 & 22,125 & 36,046 & 173,299 & 248,403 & 30,404 & 513,487 \\
\hline & Median & 695 & 1,762 & 1,152 & 2,612 & 2,583 & 1,428 & 1,855 \\
\hline & Mean & 763 & 2,213 & 2,575 & 6,665 & 6,210 & 5,067 & 5,135 \\
\hline \multirow[t]{3}{*}{ Equity Value at Premium (\$mn) } & Total & 1,714 & 16,492 & 34,107 & 132,401 & 211,317 & 24,515 & 421,577 \\
\hline & Median & 418 & 1,525 & 1,198 & 1,884 & 1,979 & 1,275 & 1,649 \\
\hline & Mean & 429 & 1,649 & 2,436 & 5,092 & 5,283 & 4,086 & 4,216 \\
\hline \multirow[t]{2}{*}{ Enterprise Value at Premium / EBITDA } & Median & 6.4 & 9.8 & 8.4 & 10.1 & 11.7 & 10.6 & 10.3 \\
\hline & Mean & 7.8 & 9.8 & 9.7 & 10.0 & 12.0 & 10.3 & 10.6 \\
\hline \multirow{2}{*}{ Premium on Equity Value (1 Day) } & Median & $39.9 \%$ & $24.7 \%$ & $15.2 \%$ & $20.5 \%$ & $18.2 \%$ & $37.7 \%$ & $20.1 \%$ \\
\hline & Mean & $43.8 \%$ & $22.3 \%$ & $18.0 \%$ & $24.2 \%$ & $21.4 \%$ & $37.0 \%$ & $24.0 \%$ \\
\hline \multirow[t]{2}{*}{ Premium on Equity Value (1 Month, adj.) } & Median & $41.6 \%$ & $24.3 \%$ & $29.1 \%$ & $23.8 \%$ & $24.3 \%$ & $37.1 \%$ & $24.6 \%$ \\
\hline & Mean & $38.2 \%$ & $25.5 \%$ & $30.4 \%$ & $24.4 \%$ & $26.9 \%$ & $33.0 \%$ & $27.6 \%$ \\
\hline ttest on difference to 1-day & & & & & & & & $* * *$ \\
\hline \multirow[t]{2}{*}{ Premium on Equity Value (2 Months, adj.) } & Median & $47.3 \%$ & $23.9 \%$ & $26.2 \%$ & $22.6 \%$ & $28.4 \%$ & $20.9 \%$ & $26.3 \%$ \\
\hline & Mean & $38.0 \%$ & $22.0 \%$ & $29.9 \%$ & $24.7 \%$ & $27.9 \%$ & $21.0 \%$ & $26.6 \%$ \\
\hline ttest on difference to 1-day & & & & & & & & $* *$ \\
\hline \multirow[t]{2}{*}{ Premium (1 Day) on Enterprise Value } & Median & $23.5 \%$ & $19.1 \%$ & $13.2 \%$ & $16.1 \%$ & $16.3 \%$ & $30.2 \%$ & $16.8 \%$ \\
\hline & Mean & $19.0 \%$ & $16.2 \%$ & $16.7 \%$ & $19.3 \%$ & $17.2 \%$ & $33.1 \%$ & $18.6 \%$ \\
\hline ttest on difference to equity premium & & & & & & & & $* * *$ \\
\hline \multirow{2}{*}{ Premium (1 Month, adj.) on Enterprise Value } & Median & $23.7 \%$ & $17.7 \%$ & $24.4 \%$ & $17.0 \%$ & $21.3 \%$ & $28.7 \%$ & $20.1 \%$ \\
\hline & Mean & $18.0 \%$ & $19.4 \%$ & $27.7 \%$ & $20.1 \%$ & $22.3 \%$ & $28.5 \%$ & $22.3 \%$ \\
\hline ttest on difference to 1-day & & & & & & & & $* * *$ \\
\hline ttest on difference to equity premium & & & & & & & & $* * *$ \\
\hline \multirow[t]{2}{*}{ Premium ( 2 Months, adj.) on Enterprise Value } & Median & $19.5 \%$ & $17.7 \%$ & $27.8 \%$ & $16.5 \%$ & $20.7 \%$ & $18.1 \%$ & $19.8 \%$ \\
\hline & Mean & $19.8 \%$ & $16.4 \%$ & $30.7 \%$ & $21.0 \%$ & $23.6 \%$ & $20.0 \%$ & $22.6 \%$ \\
\hline ttest on difference to 1-day & & & & & & & & $* * *$ \\
\hline ttest on difference to equity premium & & & & & & & & $* * *$ \\
\hline
\end{tabular}

Source: own sample data and calculations. 


\section{Table VIII - Capital structure and leverage}

This table shows the equity and debt structure, as well as the leverage of the LBOs. Private equity and leveraged debt numbers represent the total amount of contributed capital to the transactions. The sum of these numbers exceeds the enterprise value at premium (as shown in Table VII) by the amount of transaction costs and reserved cash according to the credit agreements. Percentage of equity is the fraction of equity relative to all capital. Senior debt contains all first-lien secured debt tranches. Junior debt contains second-lien secured, unsecured and subordinated debt as well as retained debt. EBITDA and Capex are normalized last-twelve months numbers prior to the agreement of the transaction. Post-LBO interest expenses refer to the drawn amounts of all LBO debt tranches with respect to the 3M US\$ LIBOR at closing plus the individual margins or the fixed interest rate instead. "Incl. PIK" assumes that interest expenses of payment-in-kind tranches are paid in cash in the first year after the LBO.

\begin{tabular}{|c|c|c|c|c|c|c|c|c|}
\hline & & 2003 & 2004 & 2005 & 2006 & 2007 & 2008 & 2003-2008 \\
\hline Number of Deals & & 4 & 10 & 14 & 26 & 40 & 6 & 100 \\
\hline \multirow[t]{3}{*}{ Private Equity (\$mn) } & Total & 1,115 & 5,798 & 11,737 & 46,837 & 71,329 & 7,241 & 144,292 \\
\hline & Median & 281 & 537 & 533 & 811 & 843 & 828 & 711 \\
\hline & Mean & 279 & 580 & 838 & 1,801 & 1,783 & 1,207 & 1,443 \\
\hline \multirow[t]{3}{*}{ Leveraged Debt (\$mn) } & Total & 2,170 & 17,563 & 27,232 & 131,535 & 185,715 & 24,375 & 388,848 \\
\hline & Median & 518 & 1,189 & 710 & 1,928 & 1,649 & 740 & 1,351 \\
\hline & Mean & 543 & 1,756 & 1,945 & 5,059 & 4,643 & 4,062 & 3,888 \\
\hline \multirow{4}{*}{ Percentage of Equity (\$mn) } & Median & $37.1 \%$ & $26.8 \%$ & $32.2 \%$ & $29.1 \%$ & $32.7 \%$ & $53.0 \%$ & $31.2 \%$ \\
\hline & Mean & $33.2 \%$ & $26.0 \%$ & $35.0 \%$ & $30.2 \%$ & $33.7 \%$ & $47.6 \%$ & $33.1 \%$ \\
\hline & Min & $20.1 \%$ & $12.0 \%$ & $15.9 \%$ & $14.7 \%$ & $16.1 \%$ & $12.6 \%$ & $12.0 \%$ \\
\hline & $\operatorname{Max}$ & $38.7 \%$ & $36.3 \%$ & $62.1 \%$ & $42.9 \%$ & $54.4 \%$ & $63.9 \%$ & $63.9 \%$ \\
\hline \multirow[t]{2}{*}{ Total Debt / EBITDA } & Median & 4.7 & 7.0 & 7.4 & 7.3 & 8.5 & 5.6 & 7.6 \\
\hline & Mean & 4.7 & 7.9 & 7.0 & 7.5 & 8.4 & 5.8 & 7.6 \\
\hline \multirow{2}{*}{ Senior Debt / EBITDA } & Median & 2.1 & 4.1 & 4.7 & 4.6 & 5.1 & 3.4 & 4.6 \\
\hline & Mean & 2.1 & 4.1 & 4.7 & 4.6 & 5.2 & 3.9 & 4.7 \\
\hline \multirow[t]{2}{*}{ Junior Debt / EBITDA } & Median & 2.6 & 3.8 & 2.3 & 3.0 & 3.4 & 2.5 & 3.0 \\
\hline & Mean & 2.6 & 3.8 & 2.3 & 2.9 & 3.2 & 2.0 & 2.9 \\
\hline \multirow[t]{2}{*}{ Interest Expenses (excl. PIK) / EBITDA } & Median & $36.2 \%$ & $46.2 \%$ & $53.6 \%$ & $57.7 \%$ & $69.0 \%$ & $48.7 \%$ & $60.3 \%$ \\
\hline & Mean & $35.8 \%$ & $51.3 \%$ & $54.2 \%$ & $58.5 \%$ & $65.6 \%$ & $52.7 \%$ & $58.7 \%$ \\
\hline \multirow[t]{2}{*}{ Interest Expenses (incl. PIK) / EBITDA } & Median & $36.2 \%$ & $46.2 \%$ & $54.7 \%$ & $61.4 \%$ & $71.1 \%$ & $52.2 \%$ & $64.6 \%$ \\
\hline & Mean & $42.1 \%$ & $51.3 \%$ & $55.7 \%$ & $61.1 \%$ & $72.6 \%$ & $53.9 \%$ & $62.5 \%$ \\
\hline \multirow[t]{2}{*}{ Interest Expenses (excl. PIK) / EBITDA-Capex } & Median & $41.1 \%$ & $77.4 \%$ & $78.3 \%$ & $81.8 \%$ & $87.8 \%$ & $79.5 \%$ & $82.2 \%$ \\
\hline & Mean & $46.0 \%$ & $72.1 \%$ & $71.9 \%$ & $80.2 \%$ & $89.8 \%$ & $79.5 \%$ & $80.7 \%$ \\
\hline \multirow[t]{2}{*}{ Interest Expenses (incl. PIK) / EBITDA-Capex } & Median & $41.1 \%$ & $77.4 \%$ & $80.2 \%$ & $84.6 \%$ & $100.9 \%$ & $83.9 \%$ & $86.8 \%$ \\
\hline & Mean & $46.0 \%$ & $72.1 \%$ & $73.6 \%$ & $83.7 \%$ & $98.5 \%$ & $80.9 \%$ & $85.4 \%$ \\
\hline
\end{tabular}

Source: own sample data and calculations. 


\section{Table IX - Tax shields for different scenarios}

This table shows the value of debt tax shields as a fraction of the paid premium, the one-month adjusted paid premium, the two-month adjusted paid premium and the pre-LBO equity and enterprise values for the median and mean company in our sample following different scenarios. We also count the number of companies for which the tax shield exceeds $100 \%$ of the premium under each scenario. Scenario 1 follows assumptions that determine a very fast repayment of debt principal and, hence, result in smaller tax shields. The assumptions of scenario 8 lead to a smaller repayment of outstanding debt principal; therefore, the tax shields are at the higher end. We also show details on the underlying assumptions that were the basis of each scenario.

\begin{tabular}{|c|c|c|c|c|c|c|c|c|}
\hline & \multicolumn{8}{|c|}{ Scenario } \\
\hline & 1 & 2 & 3 & 4 & 5 & 6 & 7 & 8 \\
\hline \multicolumn{9}{|l|}{$\underline{\text { Median }}$} \\
\hline Tax Shield as a Fraction of 1-Day Premium & $42.3 \%$ & $42.9 \%$ & $43.9 \%$ & $45.8 \%$ & $54.0 \%$ & $55.6 \%$ & $56.4 \%$ & $59.3 \%$ \\
\hline Tax Shield as a Fraction of 1-Month adj. Premium & $34.8 \%$ & $35.5 \%$ & $37.6 \%$ & $38.8 \%$ & $44.6 \%$ & $45.5 \%$ & $48.4 \%$ & $48.4 \%$ \\
\hline Tax Shield as a Fraction of 2-Months adj. Premium & $34.9 \%$ & $36.3 \%$ & $36.9 \%$ & $37.3 \%$ & $44.4 \%$ & $47.1 \%$ & $48.0 \%$ & $48.7 \%$ \\
\hline Tax Shield as a Fraction of pre-LBO EV & $7.8 \%$ & $8.1 \%$ & $8.3 \%$ & $8.4 \%$ & $10.2 \%$ & $10.6 \%$ & $11.0 \%$ & $11.1 \%$ \\
\hline \multicolumn{9}{|l|}{$\underline{\text { Mean }}$} \\
\hline Tax Shield as a Fraction of 1-Day Premium & $64.5 \%$ & $65.5 \%$ & $66.7 \%$ & $67.7 \%$ & $81.1 \%$ & $83.1 \%$ & $86.3 \%$ & $87.2 \%$ \\
\hline Tax Shield as a Fraction of 1-Month adj. Premium & $41.2 \%$ & $42.0 \%$ & $42.8 \%$ & $43.5 \%$ & $51.3 \%$ & $53.3 \%$ & $55.3 \%$ & $55.9 \%$ \\
\hline Tax Shield as a Fraction of 2-Months adj. Premium & $43.4 \%$ & $44.5 \%$ & $45.9 \%$ & $47.0 \%$ & $55.7 \%$ & $54.6 \%$ & $56.0 \%$ & $56.3 \%$ \\
\hline Tax Shield as a Fraction of pre-LBO EV & $8.0 \%$ & $8.1 \%$ & $8.3 \%$ & $8.5 \%$ & $9.9 \%$ & $10.1 \%$ & $10.4 \%$ & $10.5 \%$ \\
\hline \multicolumn{9}{|l|}{ No of Companies with a Tax Shield $>100 \%$ of } \\
\hline 1-Day Premium & 12 & 12 & 13 & 13 & 18 & 20 & 21 & 21 \\
\hline 1-Month adj. Premium & 4 & 4 & 6 & 7 & 8 & 9 & 9 & 8 \\
\hline 2-Month adj. Premium & 7 & 7 & 7 & 8 & 12 & 12 & 13 & 13 \\
\hline \multicolumn{9}{|l|}{$\underline{\text { Scenario As s umptions }}$} \\
\hline EBITDA Growth Rate & $10.0 \%$ & $10.0 \%$ & $5.0 \%$ & $5.0 \%$ & $5.0 \%$ & $5.0 \%$ & $5.0 \%$ & $0.0 \%$ \\
\hline Future Percentage of Capex & $80.0 \%$ & $90.0 \%$ & $90.0 \%$ & $100.0 \%$ & $100.0 \%$ & $100.0 \%$ & $100.0 \%$ & $100.0 \%$ \\
\hline Capex Growth Rate & $0.0 \%$ & $0.0 \%$ & $0.0 \%$ & $0.0 \%$ & $5.0 \%$ & $5.0 \%$ & $5.0 \%$ & $0.0 \%$ \\
\hline Excess Cash Flow used as Cash Sweep & $100.0 \%$ & $100.0 \%$ & $100.0 \%$ & $100.0 \%$ & $75.0 \%$ & $75.0 \%$ & $50.0 \%$ & $50.0 \%$ \\
\hline Interest Payments on PIK-Tranches? & No & No & No & No & No & Yes & Yes & Yes \\
\hline EBITDA Projections if available? & Yes & Yes & Yes & Yes & No & No & No & No \\
\hline Capex Projections if available? & Yes & Yes & Yes & Yes & No & No & No & No \\
\hline
\end{tabular}

Source: own sample data and calculations. 


\section{Table X - Debt tax shields as a determinant of LBO premia}

This table shows regressions of the LBO bid premium on various explanatory variables. The bid premium is the increase in the equity market capitalisation normalized by the enterprise value of the target before the bid. The increase in the equity market capitalisation compares the final LBO price to the stock price 1 day, 1 month, and 2 months before the first announcement. The enterprise values (1 day, 1 month and 2 months before the LBO) are computed by taking these market values of equity and adding the book value of net debt. The tax shield is the capitalized incremental tax savings according to scenario 4 in Table IX. The tax shield is also normalized by the ( 1 day, 1 month or 2 month) enterprise value. PE equity measures the fraction of the equity contribution from the private equity fund. Term Loan A (PIK) is a dummy variable that takes the value of 1 if the LBO includes an amortizing Term Loan A (PIK interest) tranche. Solebid takes the value of 0 if the initially announced bid equals the final bid price, and takes the value of 1 otherwise. T-values (using robust standard errors) are shown in brackets.

\begin{tabular}{|c|c|c|c|c|c|c|c|c|c|}
\hline & \multicolumn{9}{|c|}{ Premium / enterprise value prior to the LBO } \\
\hline & 1 day & 1 month & 2 month & 1 day & 1 month & 2 month & 1 day & 1 month & 2 month \\
\hline Tax shield / pre-LBO EV & $\begin{array}{c}0.74 * * * \\
(3.36)\end{array}$ & $\begin{array}{c}1.23 * * * \\
(5.67)\end{array}$ & $\begin{array}{c}1.68 * * * \\
(5.59)\end{array}$ & $\begin{array}{c}0.69 * * * \\
(3.51)\end{array}$ & $\begin{array}{c}1.09 * * * \\
(5.65)\end{array}$ & $\begin{array}{c}1.36^{* * * *} \\
(5.46)\end{array}$ & $\begin{array}{c}0.91 * * * \\
(3.66)\end{array}$ & $\begin{array}{c}1.18^{* * * *} \\
(5.09)\end{array}$ & $\begin{array}{c}1.49^{* * * *} \\
(4.94)\end{array}$ \\
\hline PE equity / pre-LBO EV & & & & $\begin{array}{c}0.31 * * * \\
(4.00)\end{array}$ & $\begin{array}{c}0.30 * * * \\
(4.86)\end{array}$ & $\begin{array}{c}0.44 * * * \\
(5.29)\end{array}$ & $\begin{array}{c}0.37 * * * \\
(4.38)\end{array}$ & $\begin{array}{c}0.36^{* * * *} \\
(4.84)\end{array}$ & $\begin{array}{c}0.51^{* * * *} \\
(5.62)\end{array}$ \\
\hline TL A tranche? & & & & $\begin{array}{c}-0.05 * * \\
(-2.40)\end{array}$ & $\begin{array}{l}-0.05^{*} \\
(-1.81)\end{array}$ & $\begin{array}{c}-0.10^{* * *} \\
(-2.71)\end{array}$ & $\begin{array}{c}-0.07 * * \\
(-2.37)\end{array}$ & $\begin{array}{l}-0.07^{*} \\
(-1.96)\end{array}$ & $\begin{array}{c}-0.10^{* *} \\
(-2.40)\end{array}$ \\
\hline PIK debt? & & & & $\begin{array}{c}0.01 \\
(0.30)\end{array}$ & $\begin{array}{c}-0.00 \\
(-0.02)\end{array}$ & $\begin{array}{c}0.04 \\
(1.40)\end{array}$ & $\begin{array}{c}0.03 \\
(1.26)\end{array}$ & $\begin{array}{c}0.02 \\
(0.70)\end{array}$ & $\begin{array}{l}0.05^{*} \\
(1.72)\end{array}$ \\
\hline Solebid? & & & & $\begin{array}{c}-0.00 \\
(-0.24)\end{array}$ & $\begin{array}{c}-0.01 \\
(-0.53)\end{array}$ & $\begin{array}{c}-0.00 \\
(-0.05)\end{array}$ & $\begin{array}{c}-0.00 \\
(-0.09)\end{array}$ & $\begin{array}{c}-0.01 \\
(-0.31)\end{array}$ & $\begin{array}{c}0.01 \\
(0.36)\end{array}$ \\
\hline Year fixed effects & NO & NO & NO & NO & NO & NO & YES & YES & YES \\
\hline Industry fixed effects & NO & NO & NO & NO & NO & NO & YES & YES & YES \\
\hline Constant & $\begin{array}{c}0.12 * * * \\
(6.09)\end{array}$ & $\begin{array}{c}0.11^{* * * *} \\
(5.53)\end{array}$ & $\begin{array}{c}0.08^{* * *} * \\
(3.15)\end{array}$ & $\begin{array}{c}-0.00 \\
(-0.01)\end{array}$ & $\begin{array}{c}0.00 \\
(0.13)\end{array}$ & $\begin{array}{l}-0.09^{*} \\
(-1.91)\end{array}$ & $\begin{array}{c}0.05 \\
(0.49)\end{array}$ & $\begin{array}{c}0.00 \\
(-0.01)\end{array}$ & $\begin{array}{c}-0.21^{* *} \\
(-2.21)\end{array}$ \\
\hline Observations & 100 & 100 & 100 & 100 & 100 & 100 & 100 & 100 & 100 \\
\hline R-squared & 0.10 & 0.27 & 0.33 & 0.32 & 0.45 & 0.57 & 0.45 & 0.55 & 0.64 \\
\hline
\end{tabular}

Source: own sample data and calculations. 


\section{Table XI - Regressions of debt tax shields resulting from different scenarios}

This table shows regressions of the LBO bid premium (1 day, 1 month, and 2 months before the first announcement) on the tax shields resulting from our 8 different scenarios. In each row we show coefficients and t-values (in brackets) of the explanatory variable "tax shield". The equity fraction, our dummies, as well as year and industry fixed effects were also part of these regressions.

\begin{tabular}{|c|c|c|c|c|}
\hline & & \multicolumn{3}{|c|}{ Premium / pre-LBO EV } \\
\hline & & 1 day & 1 month & 2 months \\
\hline & Scenario 1 & $\begin{array}{c}0.94 * * * \\
(3.72)\end{array}$ & $\begin{array}{c}1.24 * * * \\
(5.21)\end{array}$ & $\begin{array}{c}1.57 * * * \\
(5.08)\end{array}$ \\
\hline & Scenario 2 & $\begin{array}{c}0.92 * * * \\
(3.71)\end{array}$ & $\begin{array}{c}1.22 * * * \\
(5.16)\end{array}$ & $\begin{array}{c}1.54 * * * \\
(5.02)\end{array}$ \\
\hline$\frac{7}{0}$ & Scenario 3 & $\begin{array}{c}0.92 * * * \\
(3.69)\end{array}$ & $\begin{array}{c}1.20 * * * \\
(5.14)\end{array}$ & $\begin{array}{c}1.52 * * * \\
(4.99)\end{array}$ \\
\hline 竞 & Scenario 4 & $\begin{array}{c}0.91 * * * \\
(3.66)\end{array}$ & $\begin{array}{c}1.18^{* * * *} \\
(5.09)\end{array}$ & $\begin{array}{c}1.49 * * * \\
(4.94)\end{array}$ \\
\hline 窇 & Scenario 5 & $\begin{array}{c}0.74 * * * \\
(3.32)\end{array}$ & $\begin{array}{c}1.07 * * * \\
(5.01)\end{array}$ & $\begin{array}{c}1.38 * * * \\
(5.10)\end{array}$ \\
\hline$\underset{\sigma}{\tilde{E}}$ & Scenario 6 & $\begin{array}{c}0.75 * * * \\
(3.37)\end{array}$ & $\begin{array}{c}1.06 * * * \\
(5.00)\end{array}$ & $\begin{array}{c}1.37 * * * \\
(5.06)\end{array}$ \\
\hline & Scenario 7 & $\begin{array}{c}0.78 * * * \\
(3.61)\end{array}$ & $\begin{array}{c}1.06 * * * \\
(5.17)\end{array}$ & $\begin{array}{c}1.37 * * * \\
(5.25)\end{array}$ \\
\hline & Scenario 8 & $\begin{array}{c}0.78 * * * \\
(3.68)\end{array}$ & $\begin{array}{c}1.06 * * * \\
(5.16)\end{array}$ & $\begin{array}{c}1.35 * * * \\
(5.29)\end{array}$ \\
\hline
\end{tabular}

Source: own sample data and calculations. 


\section{Table XII - Debt tax shields based on the $35 \%$ federal tax rate}

This table shows the results of the same regressions as in Table X, with the difference that the explanatory tax shields were calculated based on the $35 \%$ U.S. federal tax rate for each company. The remaining variables don't change from our previous regression in Table X.

\begin{tabular}{|c|c|c|c|c|c|c|c|c|c|}
\hline & \multicolumn{9}{|c|}{ Premium / enterprise value prior to the LBO } \\
\hline & 1 day & 1 month & 2 month & 1 day & 1 month & 2 month & 1 day & 1 month & 2 month \\
\hline Tax shield / pre-LBO EV & $\begin{array}{c}0.76^{* * *} \\
(3.27)\end{array}$ & $\begin{array}{c}1.29 * * * \\
(5.58)\end{array}$ & $\begin{array}{c}1.79 * * * \\
(5.59)\end{array}$ & $\begin{array}{c}0.76^{* * *} \\
(3.65)\end{array}$ & $\begin{array}{c}1.19 * * * \\
(5.75)\end{array}$ & $\begin{array}{c}1.50^{* * *} \\
(5.77)\end{array}$ & $\begin{array}{c}1.01 * * * \\
(3.59)\end{array}$ & $\begin{array}{c}1.27 * * * \\
(4.60)\end{array}$ & $\begin{array}{c}1.64 * * * \\
(4.92)\end{array}$ \\
\hline PE equity / pre-LBO EV & & & & $\begin{array}{c}0.32 * * * \\
(4.09)\end{array}$ & $\begin{array}{c}0.31 * * * \\
(5.00)\end{array}$ & $\begin{array}{c}0.45^{* * *} \\
(5.58)\end{array}$ & $\begin{array}{c}0.38^{* * *} \\
(4.50)\end{array}$ & $\begin{array}{c}0.37 * * * \\
(5.01)\end{array}$ & $\begin{array}{c}0.53^{* * *} * \\
(6.01)\end{array}$ \\
\hline TL A tranche? & & & & $\begin{array}{c}-0.05^{* *} \\
(-2.28)\end{array}$ & $\begin{array}{l}-0.05 \\
(-1.60)\end{array}$ & $\begin{array}{c}-0.10^{* *} \\
(-2.53)\end{array}$ & $\begin{array}{c}-0.07^{* *} \\
(-2.16)\end{array}$ & $\begin{array}{l}-0.07^{*} \\
(-1.70)\end{array}$ & $\begin{array}{c}-0.10^{* *} \\
(-2.12)\end{array}$ \\
\hline PIK debt? & & & & $\begin{array}{c}0.00 \\
(0.17)\end{array}$ & $\begin{array}{c}-0.01 \\
(-0.24)\end{array}$ & $\begin{array}{c}0.03 \\
(1.16)\end{array}$ & $\begin{array}{c}0.03 \\
(1.30)\end{array}$ & $\begin{array}{c}0.02 \\
(0.69)\end{array}$ & $\begin{array}{l}0.05^{*} \\
(1.72)\end{array}$ \\
\hline Solebid? & & & & $\begin{array}{l}-0.01 \\
(-0.35)\end{array}$ & $\begin{array}{c}-0.02 \\
(-0.66)\end{array}$ & $\begin{array}{c}-0.01 \\
(-0.21)\end{array}$ & $\begin{array}{c}-0.00 \\
(-0.22)\end{array}$ & $\begin{array}{l}-0.01 \\
(-0.46)\end{array}$ & $\begin{array}{c}0.00 \\
(0.16)\end{array}$ \\
\hline Year fixed effects & NO & NO & NO & NO & NO & NO & YES & YES & YES \\
\hline Industry fixed effects & NO & NO & NO & NO & NO & NO & YES & YES & YES \\
\hline Constant & $\begin{array}{c}0.13^{* * *} * \\
(6.21)\end{array}$ & $\begin{array}{c}0.11^{* * *} \\
(5.56)\end{array}$ & $\begin{array}{c}0.08^{* * *} * \\
(3.02)\end{array}$ & $\begin{array}{c}-0.00 \\
(-0.12)\end{array}$ & $\begin{array}{c}0.00 \\
(0.04)\end{array}$ & $\begin{array}{c}-0.10^{* *} \\
(-2.09)\end{array}$ & $\begin{array}{c}0.05 \\
(0.50)\end{array}$ & $\begin{array}{c}0.01 \\
(0.09)\end{array}$ & $\begin{array}{c}-0.20^{* *} \\
(-2.06)\end{array}$ \\
\hline Observations & 100 & 100 & 100 & 100 & 100 & 100 & 100 & 100 & 100 \\
\hline R-squared & 0.09 & 0.27 & 0.34 & 0.33 & 0.46 & 0.59 & 0.46 & 0.55 & 0.66 \\
\hline
\end{tabular}

Source: own sample data and calculations. 
Figure I - U.S. fundraising activity between 1980 and 2007

This figure shows the annual amounts of committed capital to U.S. Private Equity funds in US\$ billion.

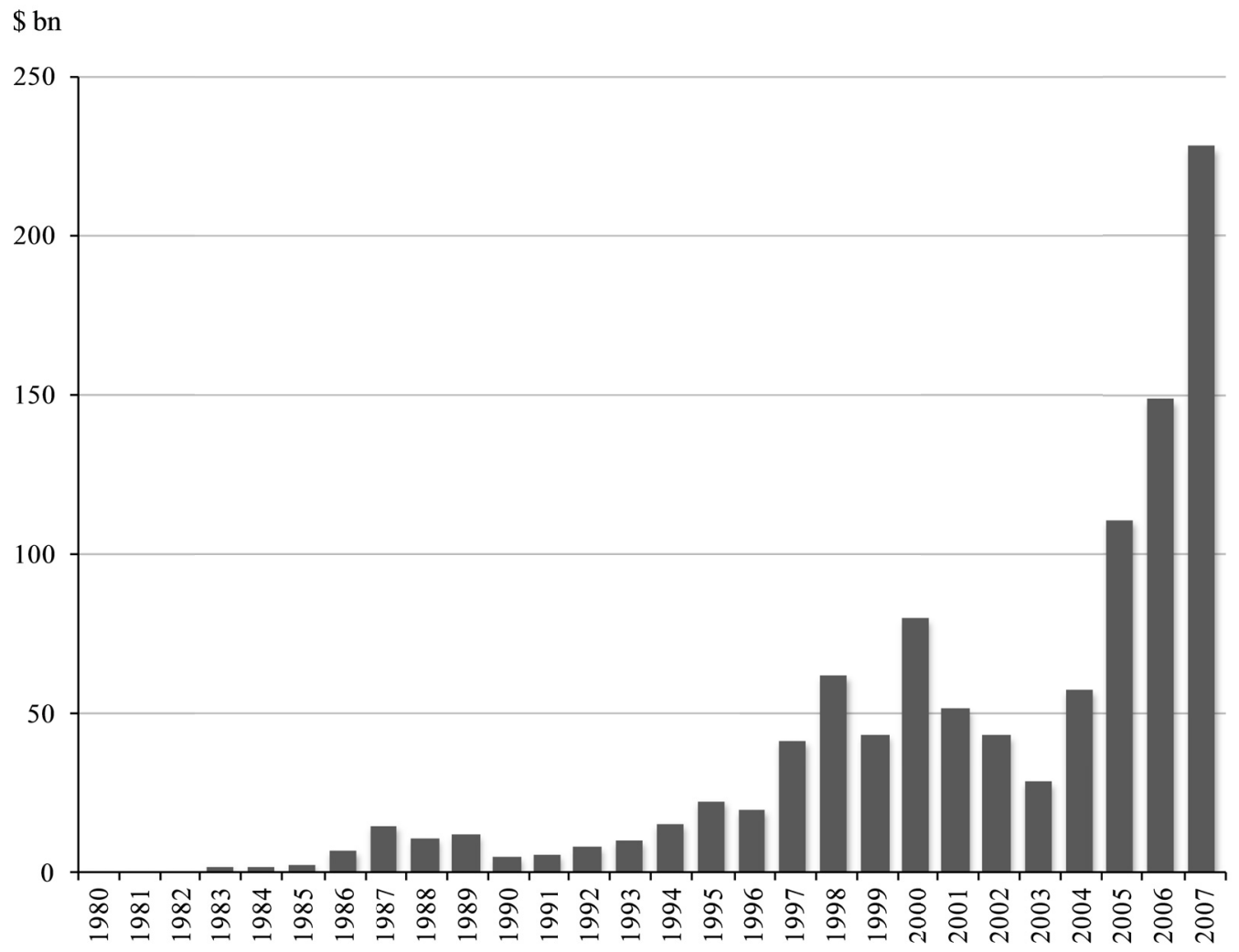

Source: Private Equity Analyst, Kaplan and Strömberg (2008), own illustration. 


\section{Figure II - Transaction premia to equity and enterprise values}

These figures show the relationship between the paid premia relative to a company's pre-LBO equity and enterprise values for the 1-day, 1-month and 2-months cases. The red squares in the first Chart indicate the magnitudes of the differences at certain levels of the conventional equity premium. Dots above the diagonal line indicate companies that had a lower enterprise value than the equity value due to negative amounts of net debt.

Chart A: One-day premia.

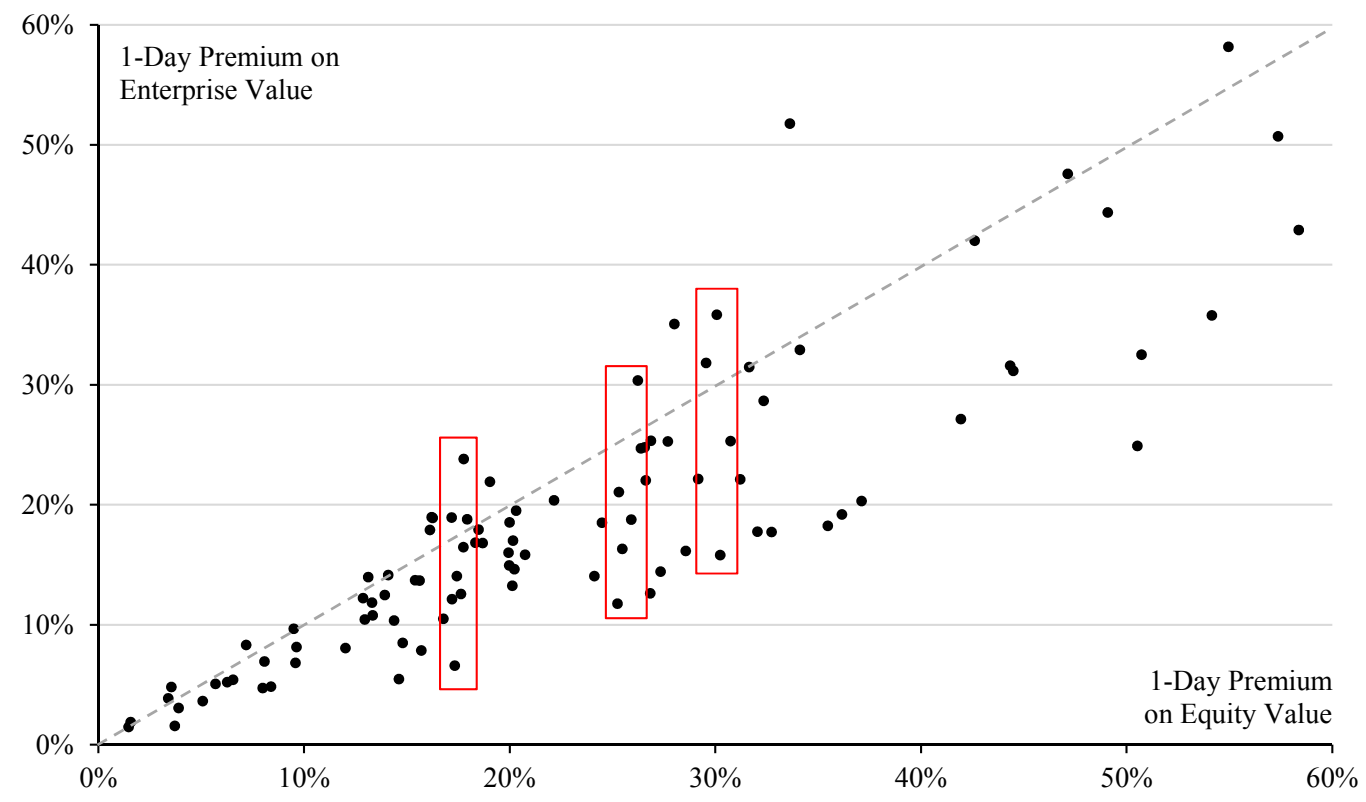

Chart B: One-month adjusted premia.

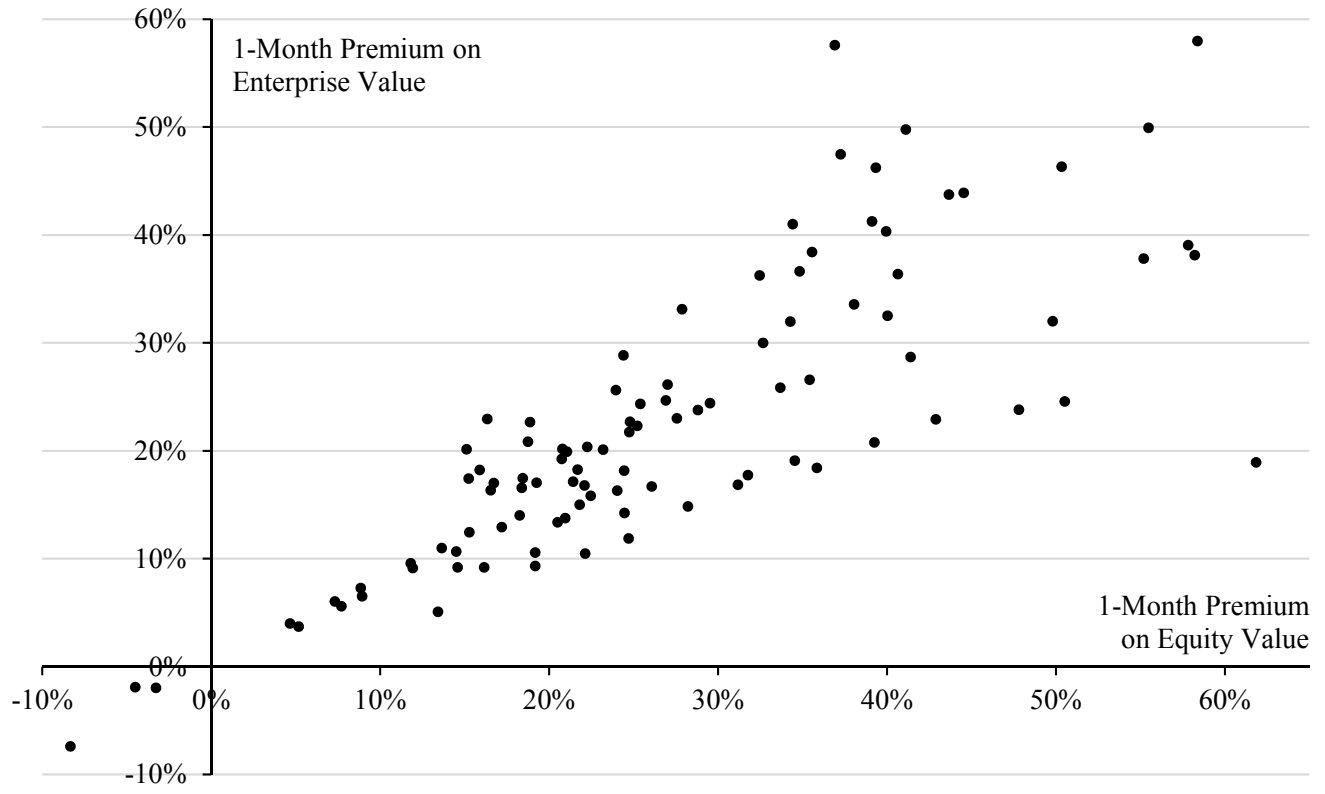


Chart C: Two-months adjusted premia.

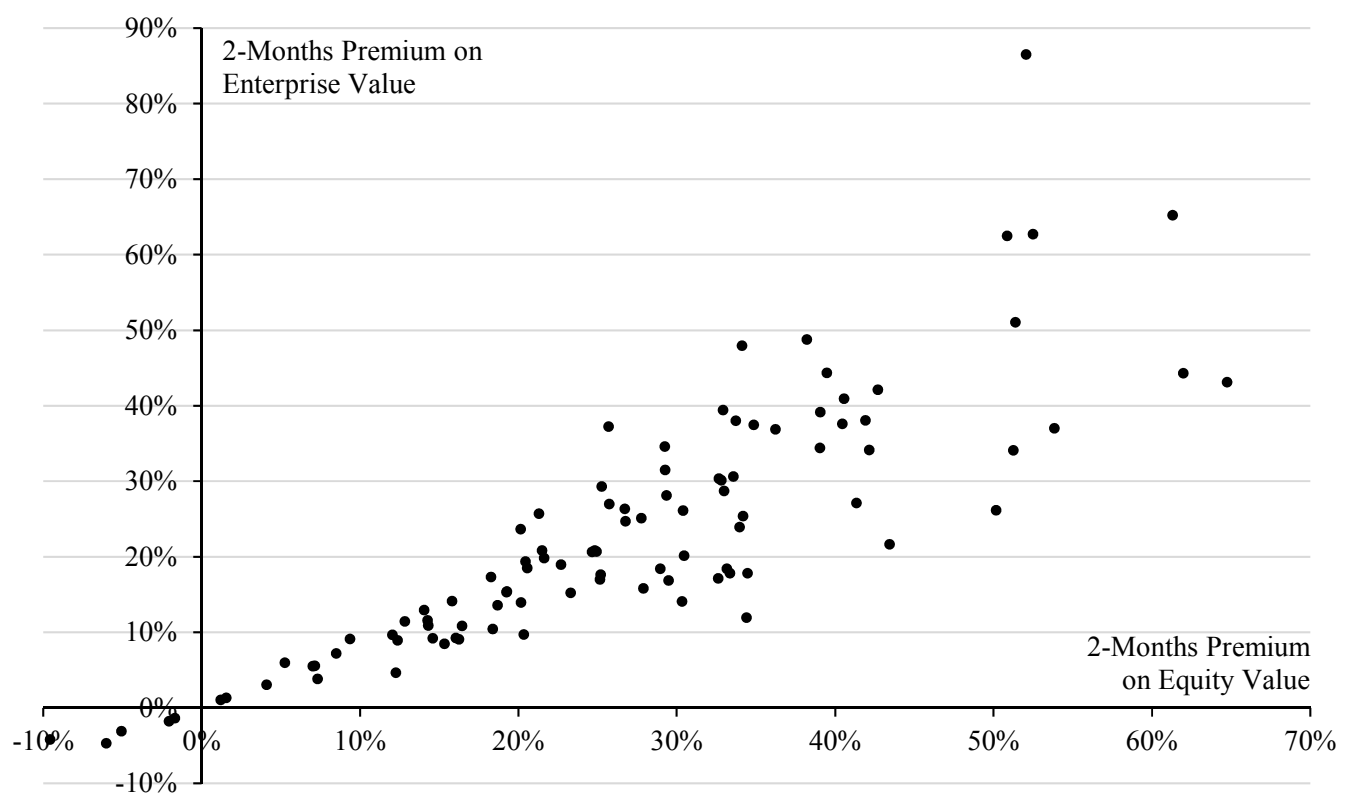

Source: own sample data, calculations and illustrations. 


\section{Figure III - Changes in a company's capital structure and interest obligation}

This figure shows the changes in the capital structure at approximated market values and the interest expenses for the average company in our sample. Prior to the announcement of a takeover the averaged equity value was $\$ 3.0$ billion plus $\$ 0.87$ billion of debt. The equity value increased to $\$ 3.7$ billion according to the final bid price per share. Immediately after the LBO the company's capital structure almost changed to the opposite. The sponsors' equity contribution had an average of $\$ 1.2$ billion. The LBO debt package had a size of $\$ 3.3$ billion of which $\$ 2.0$ billion were leveraged loans with the remainder of $\$ 1.3$ billion in high-yield notes.

The average amount of interest expenses increased from $\$ 60$ million in the year before the LBO to $\$ 250$ million in the first year after the LBO. On top of these expenses comes an average amount of \$20 million of interest expenses resulting from payment-in-kind notes.
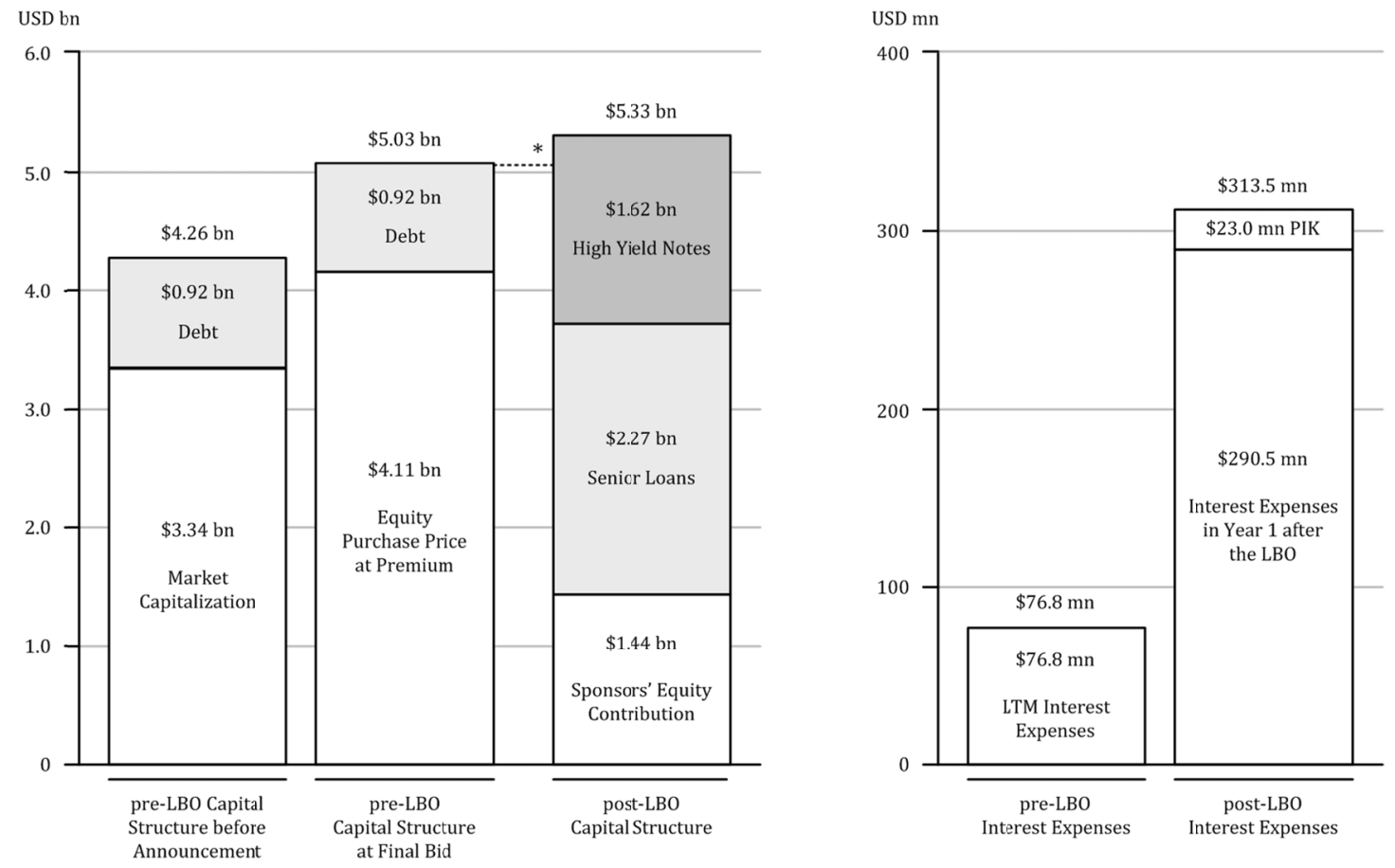

\footnotetext{
* The difference between the equity and debt funding of the LBO and the equity purchase price at premium plus the debt to retire results from the transaction costs plus the amount of restricted cash according to the new credit agreement.
}

Source: own sample data, calculations and illustration. 


\section{Figure IV - Debt principal in the years after the LBO}

This figure shows the amounts of outstanding debt principal for the two extreme scenarios, as well as Scenario 4, which we use in our regressions. Scenario 8 follows assumptions that lead to lower excess cash flows and a slower repayment of debt principal. The assumptions of scenario 1 result in higher excess cash flows that are entirely used to repay debt principal. Chart A shows the fraction of debt principal relative to the initial amount for the 10 years after the LBO. Chart B shows the ratio of debt principal relative to the increasing enterprise value.

Chart A: Remaining debt principal.

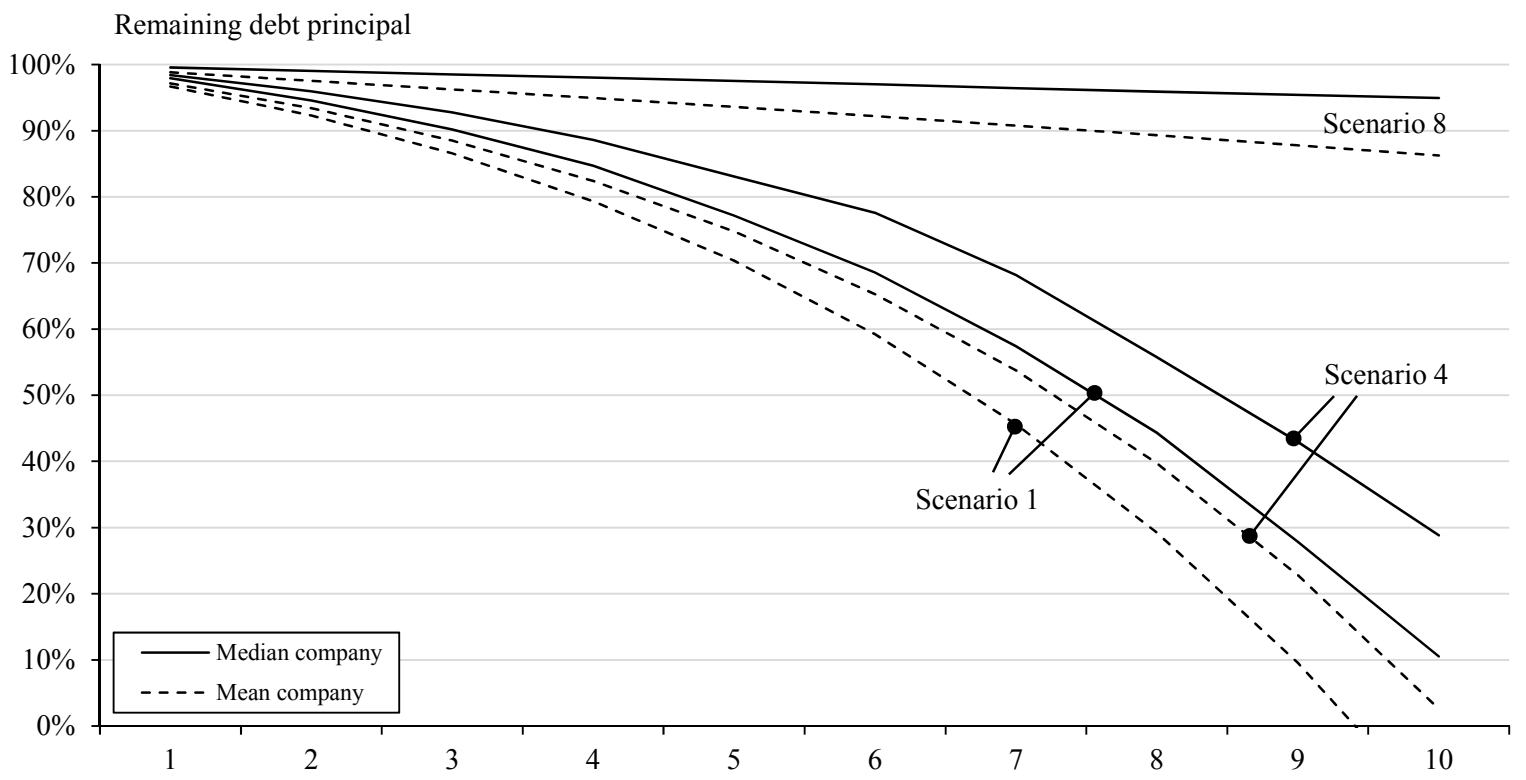

Chart B: Ratio of debt to enterprise value.

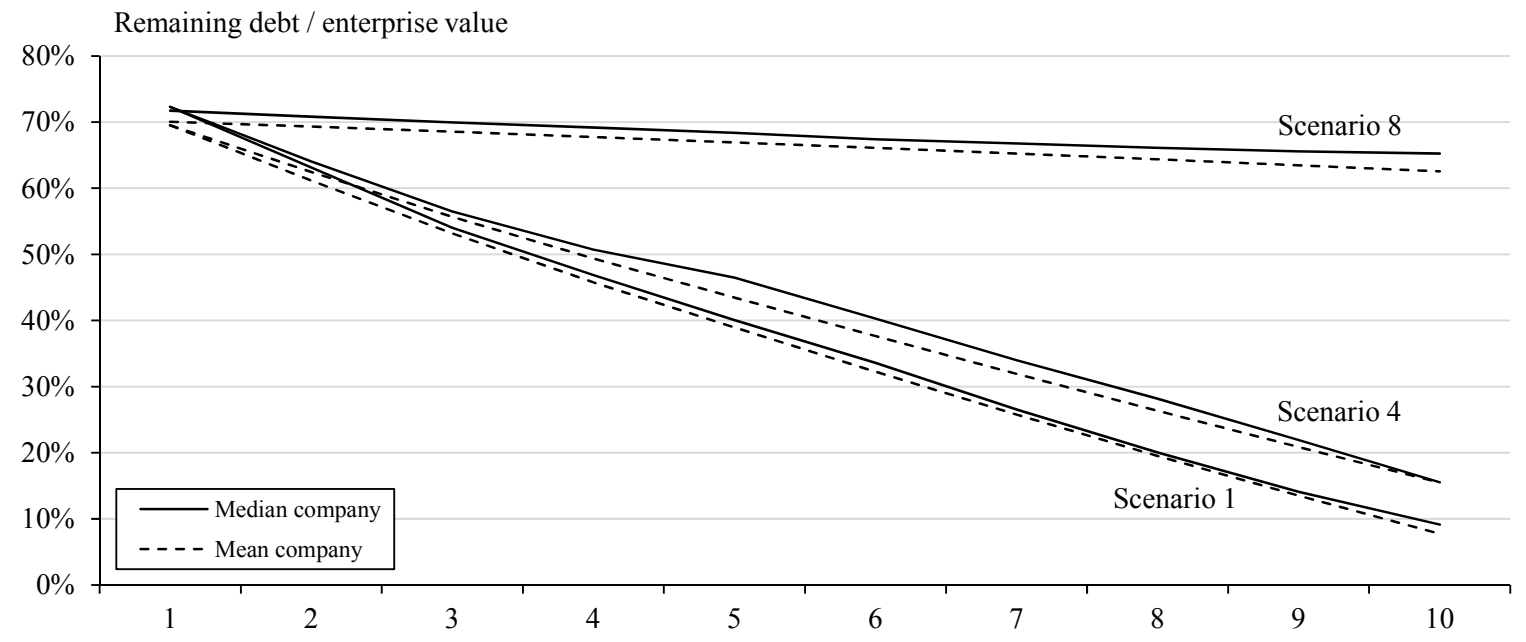

Source: own sample data, calculations and illustration. 


\section{Figure V - Tax shield in different scenarios}

This figure shows the value of debt tax shields as a fraction of the paid premium, the one-month adjusted paid premium, the two-months adjusted paid premium and the pre-LBO market capitalization for the median and mean company in our sample following different scenarios. Scenario 1 follows assumptions that determine a very fast repayment of debt principal and, hence, result in smaller tax shields. The assumptions of scenario 8 lead to a smaller repayment of outstanding debt principal; therefore, the tax shields are at the higher end. We also show details on the underlying assumptions that were the basis of each scenario.

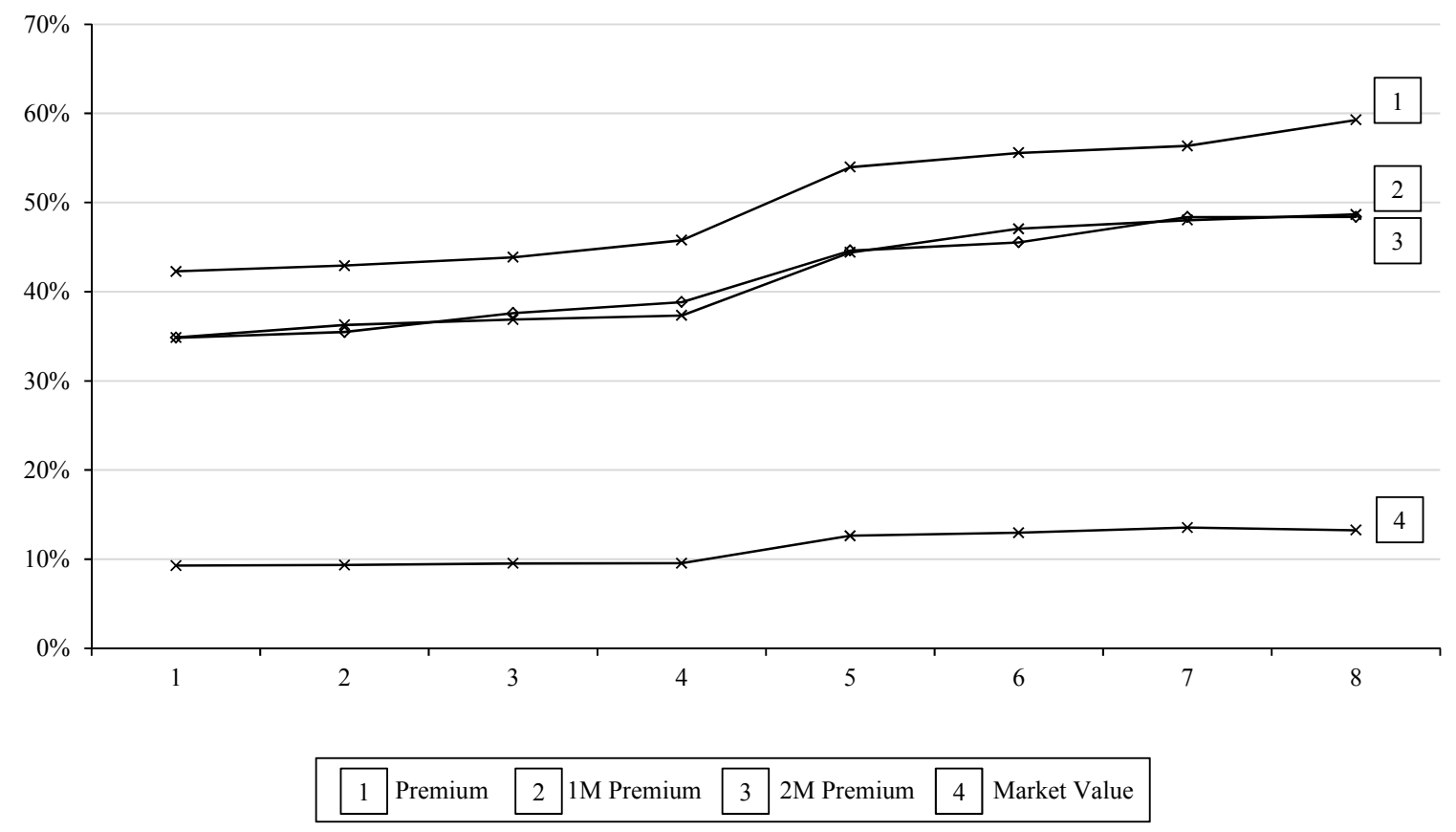

\begin{tabular}{lcccccccc}
\hline & \multicolumn{7}{c}{ Scenario } \\
\cline { 2 - 8 } & $\mathbf{1}$ & $\mathbf{2}$ & $\mathbf{3}$ & $\mathbf{4}$ & $\mathbf{5}$ & $\mathbf{6}$ & $\mathbf{7}$ & $\mathbf{8}$ \\
\hline Scenario Ass umptions & & & & & & & & \\
EBITDA Growth Rate & & & & & & & & \\
Future Percentage of Capex & $10.0 \%$ & $10.0 \%$ & $5.0 \%$ & $5.0 \%$ & $5.0 \%$ & $5.0 \%$ & $5.0 \%$ & $0.0 \%$ \\
Capex Growth Rate & $80.0 \%$ & $90.0 \%$ & $90.0 \%$ & $100.0 \%$ & $100.0 \%$ & $100.0 \%$ & $100.0 \%$ & $100.0 \%$ \\
Excess Cash Flow used as Cash Sweep & $0.0 \%$ & $0.0 \%$ & $0.0 \%$ & $0.0 \%$ & $5.0 \%$ & $5.0 \%$ & $5.0 \%$ & $0.0 \%$ \\
Interest Payments on PIK-Tranches? & $100.0 \%$ & $100.0 \%$ & $100.0 \%$ & $100.0 \%$ & $75.0 \%$ & $75.0 \%$ & $50.0 \%$ & $50.0 \%$ \\
EBITDA Projections if available? & No & No & No & No & No & Yes & Yes & Yes \\
Capex Projections if available? & Yes & Yes & Yes & Yes & No & No & No & No \\
\hline
\end{tabular}

Source: own sample data, calculations and illustration. 